\title{
Role of Phaseolus vulgaris L. in the Prevention of Cardiovascular Diseases-Cardioprotective Potential of Bioactive Compounds
}

\author{
Lyanne Rodríguez ${ }^{1}$, Diego Mendez ${ }^{1}$ (D), Hector Montecino ${ }^{1}$, Basilio Carrasco ${ }^{2}$, Barbara Arevalo ${ }^{2}$, Iván Palomo ${ }^{1, *}$ \\ and Eduardo Fuentes $1, *$ (D)
}

1 Thrombosis Research Center, Department of Clinical Biochemistry and Immunohematology, Faculty of Health Sciences, Medical Technology School, Universidad de Talca, Talca 3460000, Chile; lyrodriguez@utalca.cl (L.R.); diego.mendez@utalca.cl (D.M.); hector.montecino@utalca.cl (H.M.)

2 Centro de Estudios en Alimentos Procesados, Talca 3460000, Chile; bcarrasco@ceap.cl (B.C.); barevalo@ceap.cl (B.A.)

* Correspondence: ipalomo@utalca.cl (I.P.); edfuentes@utalca.cl (E.F.)

Citation: Rodríguez, L.; Mendez, D.; Montecino, H.; Carrasco, B.; Arevalo, B.; Palomo, I.; Fuentes, E. Role of Phaseolus vulgaris L. in the Prevention of Cardiovascular Diseases-Cardioprotective Potential of Bioactive Compounds. Plants 2022, 11, 186. https://doi.org/10.3390/ plants11020186

Academic Editors: Marcello Iriti and Sara Vitalini

Received: 30 November 2021

Accepted: 1 January 2022

Published: 11 January 2022

Publisher's Note: MDPI stays neutral with regard to jurisdictional claims in published maps and institutional affiliations.

Copyright: (C) 2022 by the authors. Licensee MDPI, Basel, Switzerland. This article is an open access article distributed under the terms and conditions of the Creative Commons Attribution (CC BY) license (https:// creativecommons.org/licenses/by/ $4.0 /)$.

\begin{abstract}
In terms of safe and healthy food, beans play a relevant role. This crop belongs to the species of Phaseolus vulgaris L., being the most consumed legume worldwide, both for poor and developed countries, the latter seek to direct their diet to healthy feeding, mainly low in fat. Phaseolus vulgaris L. stands out in this area-an important source of protein, vitamins, essential minerals, soluble fiber, starch, phytochemicals, and low in fat from foods. This species has been attributed many beneficial properties for health; it has effects on the circulatory system, immune system, digestive system, among others. It has been suggested that Phaseolus vulgaris L. has a relevant role in the prevention of cardiovascular events, the main cause of mortality and morbidity worldwide. Conversely, the decrease in the consumption of this legume has been related to an increase in the prevalence of cardiovascular diseases. This review will allow us to relate the nutritional level of this species with cardiovascular events, based on the correlation of the main bioactive compounds and their role as cardiovascular protectors, in addition to revealing the main mechanisms that explain the cardioprotective effects regulated by the bioactive components.
\end{abstract}

Keywords: cardiovascular diseases; Phaseolus vulgaris L.; beans; bioactive compounds; cardioprotective

\section{Introduction}

Cardiovascular disease (CVD) is the leading cause of death in modern societies [1] and has a substantial economic impact [2]. CVD claimed more than 10 million lives in the last 18 years [3]. Conversely, many people suffer disability after suffering cardiovascular events [4]. Ninety percent of CVD deaths are attributed to conventional cardiovascular risk factors (CVRF) [5,6], which increase the probability of suffering from CVD [7]. There are non-modifiable CVRFs such as age and genetic predisposition [8,9]. Conversely, there are modifiable CVRFs: smoking, dyslipidemia, arterial hypertension, diabetes, physical inactivity, and overweight/obesity [5,6].

Platelets are considered the main pathological risk factors for CVD, such as coronary artery disease and atherosclerosis [1]. They are known for their fundamental contributions to thrombosis and hemostasis $[10,11]$. Platelet activation plays a fundamental role in the development of arterial thrombosis, for which the control of platelet function is essential for the prevention of thrombotic events [12].

Diet and lifestyle are modifiable risk factors that can have a significant impact on the probability that an individual develops different diseases [13-15].

Nutritional status is an important factor in preparing the immune system to fight infection or prevent non-communicable diseases $[13,16]$. Diet can have beneficial effects 
on several CVD risk factors [2], due to its cardioprotective and antiplatelet effects in the primary and secondary prevention of CVD [1]. Certain components of the diet with antiplatelet activity can reduce blood platelet activation and have an important influence on the treatment of cardiovascular events [2]. It has been described that there is an inverse association between antioxidants from the diet and the development of thrombosis and other coronary events $[12,17,18]$.

Many foods are considered functional because they provide nutrients and energy to support daily life [19]. Grain legumes contain high amounts of protein, minerals, and vitamins and play an important role in both agricultural systems and the human diet, mainly in developing countries [20,21]. Out of 13,000 species, only between 10 to 12 play a relevant role today, either for application in the food industry or other commercial purposes $[22,23]$. Among them, we can mention common beans (Phaseolus vulgaris), chickpeas (Cicer arientinum L.), lentils (Lens esculenta), peas (Pisum sativum), and broad beans (Vicia faba) [21].

Grain legumes are a considerable source of nutrients and have also been referred to as the meat of the poor [24], because of their importance for consumption in third world, countries where malnutrition is a relevant nutritional problem [25,26]. In general, beans are recognized as a good source of protein, 2-3 times greater than that of cereal grains [26,27]. In ancient times, protein of animal origin was consumed mainly. Recently, there is a trend toward a Mediterranean diet, which includes foods of plant origin rich in nutrients that help reduce cholesterol levels in the population, among other health benefits [1].

Thus far, there are not many reports of the natural bioactive components with cardioprotective activity present in P. vulgaris. Certainly, elaborating on the subject could be a promising target in the prevention of CVD. The research aims to improve the lifestyle of the population by showing the nutritional value of beans and how this composition can be related to cardiovascular protection, thus promoting the consumption of this legume with properties that favor the maintenance and functioning of the body.

A literature review of research articles and bibliographic reviews was carried out in bibliographic databases: Pubmed, ScienceDirect, and GoogleScholar. Articles published between 2000 and 2021 were mainly selected, using terms: CVD; Phaseolus vulgaris L.; beans; bioactive compounds; cardioprotective; nutritional composition. Key articles were selected in the reference section of the original research to broaden the search. The inclusion criteria were all articles in English; some in Portuguese were also reviewed.

\section{Phaseolus vulgaris $\mathrm{L}$.}

The common bean (Phaseolus vulgaris L.) is known as a "new world crop"; it originated 7000 years ago in two different parts of the North and South American continents $[19,28,29]$

It belongs to the genus Phaseolus, family Leguminosae, subfamily Papilionoideae, tribe Phaseoleae, subtribe Phaseolinae; it is the legume species with the highest distribution and consumption of genus Phaseolus, which comprises about 70 species [29]. It has five cultivars domesticated in the pre-Columbian era, domesticated species: common bean (Phaseolus vulgaris L.), lima bean (P. lunatus L.), red bean (Phaseolus coccineus L.), tepary bean (P. acutifolius Gray A.), and beans (P. polyanthus Greenman), which present different adaptations and reproductive systems: mesic and temperate, predominantly self-pollinated [29,30].

Phaseolus vulgaris L. represents more than $90 \%$ of the crop grown in the world [29,31]. It is considered a non-centric crop with at least two domestication centers [32] and wide geographic distribution of its wild relatives in Central and South America. This crop was domesticated from wild Phaseolus vulgaris L., an indeterminate viniferous plant, distributed from Mexico to Argentina, mainly in mid-altitude neotropical and subtropical regions [33]. This species is an important food for rural and urban populations, mainly in Latin America and East Africa, although its demand has currently increased in developed countries, where populations are worrying about maintaining healthier diets [32]. Phaseolus vulgaris L., compared to other food crops, shows great diversity in terms of growth habits, seed characteristics (size, shape, and color), maturation times, and adaptation [34]. 
The common bean is the most important legume in the world for both human consumption and animal feed [30]. Its consumption is aimed especially at low-income people [25]. In areas such as Mexico, Central, and South America, and African countries, there is a high consumption and are considered as staple foods, considering a per capita intake of up to $40 \mathrm{~kg}$ per year $[26,35,36]$. The leading countries in the production of these legumes are Latin America and sub-Saharan Africa, where three-quarters of this crop is grown, with a production of around 12 million metric tons per year [20,37]. The forms of consumption are varied; consumers of beans from different countries and regions, even within the same country, show different predilections according to the size, shape, and color of the seed, as well as cooking time, the appearance of the broth and shape of storage $[38,39]$.

Phaseolus vulgaris L. is consumed mainly by its dry grains (ripe), peel beans (seeds in physiological maturity), and green pods [30,33]. Beans are not only used as a dry grain, green beans are consumed as vegetables [29]. The seeds can be used in multiple ways, such as whole unprocessed seeds, as part of mixes, canned goods, or as a substitute for gluten-free wheat flour [19]. The United Nations for Food and Agriculture (FAO) in 2016 reported world production of a dry grain of 26.8 million tons, while the production as vegetable or green bean was 23.5 million tons. The most important classes of dried beans include green beans [26], red kidney beans [40], black beans [41], beans Mexican [42], pinto beans, tirage beans [43], great northern beans, navy beans, and pink beans [26,36].

Subtypes of Bean in Chile

Despite the nutritional value of beans and their consumption in Chile, there are few studies of these crops, which date back to before 2000. Food entities recommend this product as a component of a safe diet. Several cultivars are spread and consumed throughout Chile, achieving a high impact on the national diet [21]. The consumption of beans in Chile is under $1.5 \mathrm{~kg}$ per capita/year [44], in comparison with the 10 to $17 \mathrm{~kg}$ per capita/year consumed in Central American countries, and more than $50 \mathrm{~kg}$ per capita in some African countries [45].

The common bean germplasm collected in Chile has been classified as races Chile, Nueva Granada, Peru, Durango, and Mesoamerica, with the only exception to the race Jalisco. The Chilean strain has distinguished itself as an important source of genetic diversity [46]. This situation could be associated with commercial reasons and mainly due to the excellent adaptation of bean species to Chilean agro-climatic conditions. The current bean collection in Chile consists of 1110 accessions [38].

In most Chilean markets, the most consumed dried beans are Tortola and Coscorrón [47]. In some specific rural areas other crops, Manteca, Sapito, and Cuyano, are also consumed regularly [48]. There are other types consumed on a smaller scale, such as "bayos" and "sulfur", all of a single seed color, but it is also common to find grains of two or more colors, such as "strawberries", "araucano" and "sapito", among others [49]. Dry grain preferences in Chile are directed mainly to the texture of the cooked grain.

The Chilean race has been characterized as a sub-center of genetic diversity. A distribution analysis comprised 1239 accessions that evaluated the genetic diversity present in 11 morphological characters. Great growth variability was evidenced (leaf, flower color from white to purple, presence of all types of bracteoles, diversity of shape, size, and color of pods with dorsal or central apex). The seed showed variations in size (small to large), shape (round to elongated), and great variation in the primary color or their combination. These results were useful for the genetic improvement of "tórtola" and "coscorrón" types [49]. A recent study suggests that the Chile race would be the oldest reservoir of genetic diversity in the Andean pool, making this germplasm a relevant genetic resource [50].

There is little information on the content of minerals, flavonoids, phenolic acids, total phenols, tannins, cooking quality, and antioxidant capacity of common beans of the Chile breed [38]. A study carried out by Paredes et al., 2009, evaluated the macro and micronutrient variability of a representative sample of beans from a Chilean breed collection, comparing them with representatives of other breeds. The results showed the existence of a wide variability for some macro and micronutrients, such as N, Fe, and Zn. 
The protein content ranged from 183.5 to $259.7 \mathrm{mg} \mathrm{kg}^{-1}$, Fe from 68.9 to $152.4 \mathrm{mg} \mathrm{kg}^{-1}$, and $\mathrm{Zn}$ from 27.9 to $40.7 \mathrm{mg} \mathrm{kg}^{-1}$. The bean genotypes of the Chile breed showed a good level of protein, $\mathrm{Fe}$, and $\mathrm{Zn}$; they did not show significant differences with the genotypes of other breeds [38]. This study allowed the selection of outstanding crops within the Chilean breeds studied, also allowing to improve current crops.

The National Institute of Agricultural Research (INIA) some years ago evaluated the proximal chemical composition and the biological quality of the protein of five new cultivars in comparison with two traditional cultivars of Phaseolus vulgaris L. The beans provided a large fraction of proteins and other nutrients. Dried beans also stood out for the nutritional quality of their protein, carbohydrates, minerals, and dietary fiber [21].

\section{Relationship between Nutritional Composition and Health Benefits}

Common beans have been highlighted as an almost perfect food due to their high content of protein, fiber, prebiotics, vitamins, and chemically diverse micronutrient composition. They have been shown to protect against oxidative stress, CVD, diabetes mellitus, metabolic syndrome, and many types of cancer [19]. Many compounds have been identified in P. vulgaris, such as phenolic acids (chlorogenic acid, syringic acid, caffeic acid), flavonoids (kaempferol, pelargonidin, cyanidin, delphinidin), sugars, fatty acids, and tocopherols, among others [51] (Figure 1).

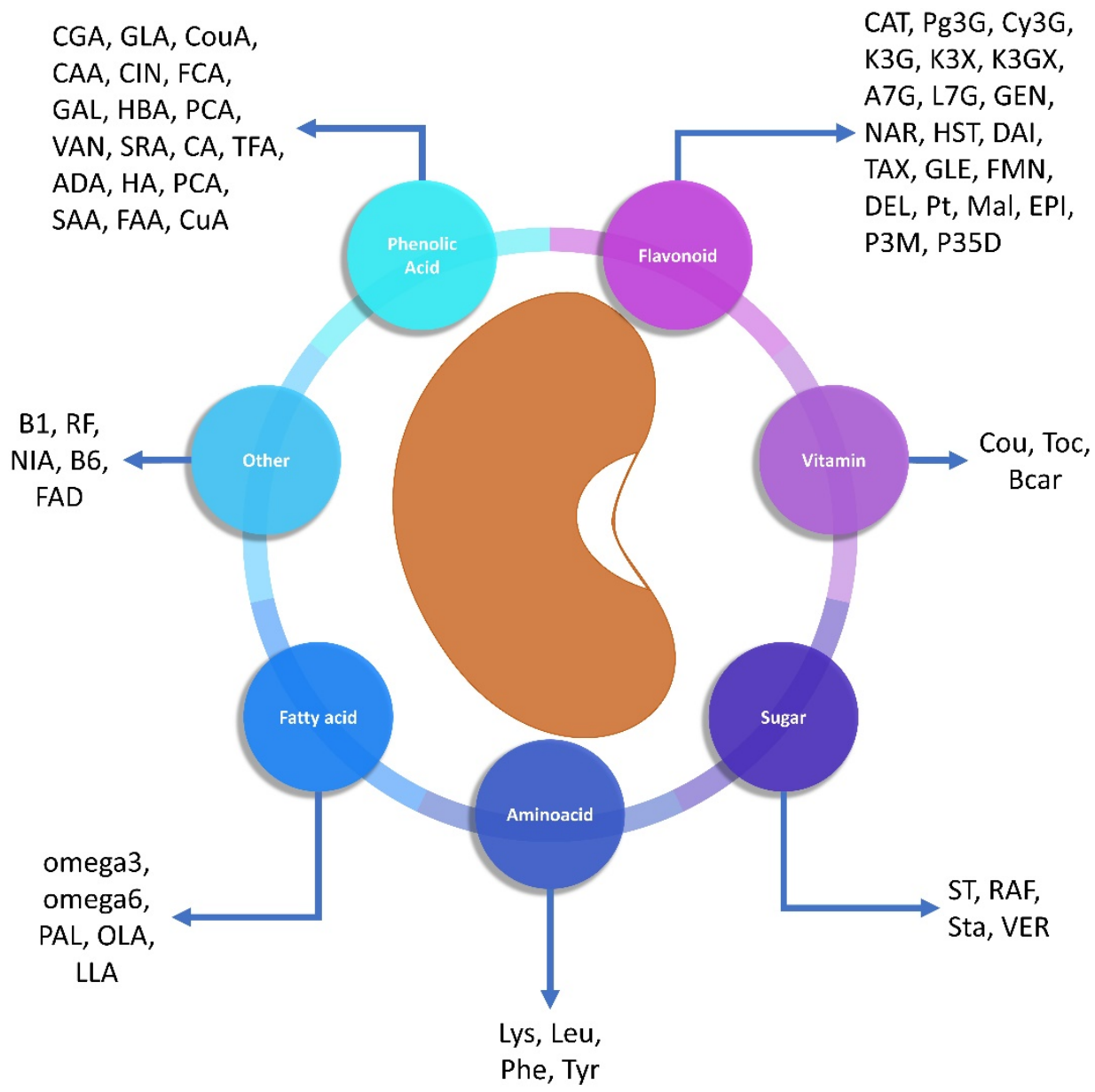

Figure 1. Compounds identified in Phaseolus vulgaris L. A7G: apigenin-7-glucoside [51], ADA: aldaric acid [51], B1: thiamine [33], B6: vitamin B6 [33], Bcar: $\beta$-carotene [52], CA: kaphtharic acid [53], CAA: caffeic acid [51], CAT: catechin [52], CGA: chlorogenic acid [54], CIN: cinnamic acid [51], Cou: coumetrol [51], CouA: coumaric acid [51], CuA: p-coumaryl aldaric acid [55], Cy3G: cyanidin-3- 
glucoside [52], DAI: daidzein [51], DEL: delphinidin [51], EPI: epicatechin [56], FAA: feruloyl aldaric acid [51], FAD: folic acid [33], FCA: ferulic acid [51], FMN: formononetin [51], GAL: gallic acid [51], GEN: genistein [51], GLA: syringic acid [54], GLE: glycitein [51], HA: synapic acid [51], HBA: hydroxybenzoic acid [51], HST: hesperetin [51], K3G: kaempferol-3-glucoside [57], K3GX: kaempferol 3-glucosylxilosido [57], K3X: kaempferol 3-xylosylglucoside [57], L7G: luteolin-7-glycoside [51], Leu: leucine [58], LLA: linolenic acid [26], Lys: lysine [58], Lys: lysine [58], Mal: malvidin [51], NAR: naringenin [51], NIA: niacin [33], OLA: oleic acid [59], omega-3: omega-3 [54], omega-3: omega-3 [54], omega-6: omega-6 [54], P35D: pelargonidin 3,5-diglycoside [51], P3M: pelargonium3-(6"-malonyl)glucoside [51], PAL: Palmitic acid [59], PCA: Protocatechuic acid [51], PCA: Palmitic acid [56], Pg3G: Pelargonidin-3-glucoside [52], Phe: phenylalanine [58], Pt: petunidine [51], RAF: raffinose [60], RF: riboflavin [33], SAA: sinapil aldaric acid [55], SRA: syringic acid [51], ST: starch [54], Sta: Stachyose [60], TAX: taxifolin [51], TFA: transferulic acid [51], Toc: tocopherol [52], Tyr: tyrosine [58], VAN: vanilic acid [51], VER: verbascosa [60]. Source: created by the authors.

Dried beans are an enriched source of protein, essential vitamins, minerals, soluble fiber starch, phytochemicals, and are low in fat. Beans have been characterized as a functional food because it has a varied content of bioactive compounds, among which the following stand out enzyme inhibitors, lectins, phytates, oligosaccharides, and phenolic substances that have an effect on the metabolism in humans and animals that consume frequently this food $[38,61]$.

The protein content of beans varies between 16-33\%, differences attributed to the environment, crops, years, geographical location, climate, soil conditions, and fertilization [62]. Bean proteins are rich in lysine and poor in methionine and cysteine, being a good complement to cereal proteins, which are deficient in lysine but rich in these sulfur amino acids $[30,34]$. It ranks as the main source of protein for vegetarians, as well as for lowincome age groups throughout the world [63]. This species is used together with cereal to obtain essential amino acids at a low cost [47]. The use of beans rich in protein together with the consumption of cereals offers the best strategy to combat the problem of malnutrition [26,64]. This food strategy is in practice in Latin America, East Africa, and most of Asia [26,27,45].

Beans contain high amounts of glutelin (20-30\%) compared to other legumes $[65,66]$. Glutelins are proteins that are not evenly dispersed over the entire surface of the grain; $80 \%$ are practically condensed in the endosperm. Globulins constitute the main fraction in beans, representing between $50-70 \%$ of total proteins [26]. The phaseolin is present between $40-50 \%$ of the total seed. Prolamine (2-4\%) and the set of free amino acids (5-9\%) are the other nitrogenous fractions of beans [67].

The amino acid content in common beans has been reported to be variable, although most authors report that the main amino acids are lysine (10-104 $\left.\mathrm{mg} \mathrm{g}^{-1}\right)$, leucine (14-92 $\left.\mathrm{mg} \mathrm{g}^{-1}\right)$, and phenylalanine + tyrosine (53-105 $\mathrm{mg} \mathrm{g}^{-1}$ ) [63]. Conversely, beans lack the sulfur amino acids, methionine + cysteine $\left(4.0-20 \mathrm{mg} \mathrm{g}^{-1}\right)$ [68-70]. Amino acids participate in the regulation of metabolism for growth, development, and homeostasis of the body [71]. Some studies show that a diet supplemented with arginine, glutamine, leucine, and cysteine has a positive impact on health [58,72].

Carbohydrates are the main component of beans; they are found in significant quantities between $50-60 \%$ of the dry matter $[26,73,74]$. Among the carbohydrates contained in beans, the one with the highest proportion and availability is starch. Bean starch can be degraded into oligodextrin and glucose by different enzymes such as -and $\beta$ amylases [26,75,76]. We also find carbohydrate derivatives such as oligosaccharides [26,77]. The starch, dietary fiber, and non-starch polysaccharides (pectins, gums, hemicelluloses, inulin, fructans, stachyose, and raffinose) present in pinto beans can support the microbiome and/or fermentable products, benefiting the functioning of the gastrointestinal tract [19]. 
The fat content in Phaseolus vulgaris L. was found to be $2.20-5.03 \%$ [29]. The main lipid components in beans are phospholipids and triacylglycerols, while minor amounts of diacylglycerols may also be present (hydrocarbons, esters, and hydrocarbons). These lipids can also take the form of phosphatidylcholine, phosphatidylethanolamine, and phosphatidylinositol in beans $[26,78]$. Butter beans contain high amounts of saturated fatty acids, $28.7 \mathrm{~g} / 100 \mathrm{~g}[26,79]$, where we find palmitic and stearic acids.

Polyunsaturated fatty acids represent an important class of lipid compounds present in this species, specifically omega fatty acids (linoleic acid (n-6) and alpha-linolenic acid (n-3) [19]; they comprise $61 \%$ of the total fatty acids together with palmitic, oleic [59]. Linolenic acid is dominant among unsaturated fatty acids, constituting $43.1 \%$ of the fatty acids in beans $[26,80]$. It was reported that linoleic and linolenic fatty acids are most of the fat of beans. Oleic and linoleic acids in common beans were determined between $7.8-13.8 \%$ and 16.7-25.8\%, respectively [29]. Epidemiological studies evidence a favorable effect on the health of patients with coronary heart disease when fed alpha-linolenic acid [19]. Omega fatty acids have a positive effect against obesity, strengthen the immune system and prevent the development of dyslipidemia. In addition to being physiologically and biochemically essential for bodily functions, they also play an important role in the development of healthy tissues [29].

Phaseolus vulgaris L. contains a rich variety of phytochemicals with antioxidant activity, such as phenolic acids, flavonoids, flavanols, isoflavones, anthocyanins, and proanthocyanidins $[23,26,81]$. The anticancer activity of beans has been attributed mainly to their polyphenolic compounds [82-84].

Soluble vitamins such as thiamine, riboflavin, niacin, vitamin B6, and folic acid have been identified in common beans [35]. Results indicated the presence of wide variability of macro and micronutrients such as $\mathrm{K}, \mathrm{Ca}, \mathrm{Mg}, \mathrm{Zn}, \mathrm{Cu}$ and Fe [12]. A higher content of Fe and $\mathrm{Ca}$ has been detected in seeds of wild beans compared to those of domesticated local varieties and other improved cultivars [33]. Sangronis and Machado identified phytic acid, tannins, ascorbic acids, thiamine, and minerals as $\mathrm{Ca}, \mathrm{Mg}, \mathrm{Zn}, \mathrm{Fe}$ and $\mathrm{Cu}$ [85]. The essential minerals, Se, Fe, and $\mathrm{Zn}$, are of great importance for human health. It has been identified that Se strengthens the immune system and reduces the risk of cancer [29]. Anemia, for example, is caused by Fe deficiency; it has been described that there are more anemic people in developing countries than in Europe and the United States [29]. Paredes et al., 2019, indicated the presence of wide variability of macro- and micronutrients: N, Fe, and $\mathrm{Zn}$ in bean genotypes previously classified as Chile race. These showed an adequate level of proteins, Fe and Zn; additionally, they did not show significant differences with genotypes of other races. The content of $\mathrm{N}$ was positively related with the proteins, $\mathrm{P}, \mathrm{Cu}$ and $\mathrm{Zn}$, while the content of Fe was correlated with $\mathrm{Mn}$, and the content of $\mathrm{Ca}$ and $\mathrm{Zn}$ was correlated with the content of $\mathrm{N}, \mathrm{P}, \mathrm{Cu}$, and S [38].

The levels of B vitamins present are considerably high. One cup of beans (225 $\mathrm{g}$ cooked) provides approximately $74 \%$ folic acid, which has multiple biological functions, deoxyribonucleic acid synthesis, repair, and methylation, as well as acting as a cofactor in many reactions. Folic acid is necessary to prevent anemia in children and adults. Dried beans contain vitamins $\mathrm{A}$ and $\mathrm{C}$ that represent $3 \%$ to $8 \%$ of the daily reference intake. One cup of beans provides adequate amounts of vitamin B6, E, K, and thiamine. Vitamin $\mathrm{E}$ is a powerful antioxidant and anti-inflammatory agent. Intake of vitamin $\mathrm{K}$ is widely associated with bone health and anti-cancer properties [19]. The consumption of approximately $\frac{1}{2}$ cup of dry beans or peas is related to a higher intake of fiber, protein, folic acid, $\mathrm{Zn}, \mathrm{Fe}$, and $\mathrm{Mg}$, while conversely shows a lower intake of saturated fat and total fat [86].

It can be said that the consumption of beans is associated with favorable effects on health, such as cholesterol level reduction and coronary heart disease, cancer diseases, reduction of diabetes and obesity, antioxidant power, antimutagenic and antiproliferative, among many others $[38,41,83,87-89]$. 


\section{Role of Beans in CVD}

\subsection{Effect on Hemostasis and Platelet Aggregation}

The complex pathophysiological process involved in CVD includes the participation of platelets; these have a main role during thrombosis and progression of atherosclerosis [90]. Food supplements and/or nutraceuticals have become attractive alternatives to reduce cardiovascular events [91].

The methanolic extract of Phaseolus vulgaris L. had been considered relevant by its antiplatelet effect, especially the ability to suppress platelet secretion, using the proposed mechanism of protein kinase A (PKA) modulation and the inhibition of AKT phosphorylation [92].

It is hypothesized that some flavonoids (kaempferol, epicatechin, delphinidin, cyanidin) can inhibit the platelet function by suppressing the platelet aggregation, calcium mobilization, integrin modulation, granule secretion, and thrombus formation, using as an example the pharmacological action of nobiletin [93].

Furthermore, other proteins can increase the activation of platelets, as is the case of lectins; these are proteins sometimes referred to as an antinutrient for decreasing the body's ability to absorb nutrients, but this review will be focusing on the lectins-induced stimulation of fresh platelets [94].

These lectins have shown effect through phospholipase C (PLC) $y / 2$ activations, using the Src/Syk and PI3K/BTK pathways, but also an increase in the reactive oxygen species (ROS), as well as superoxide anion formation and lipid peroxidation by working as an uncoupling agent with the consequent increase in oxygen consumption and decrease in adenosine triphosphate (ATP) formation $[95,96]$. This activation was completely inhibited by the use of penicillin $\mathrm{G}(12.5 \mathrm{mM})$ and cephalothin $(12.5 \mathrm{mM})$ [97].

Another interesting discovery is the Phaseolus vulgaris L. agglutinin production of nitric oxide (NO), regulated by the $\mathrm{Ca}^{2+} /$ calmodulin kinase/AMPK pathway in a time and dose-dependent manner. This process is dependent on the eNOS phosphorylation involving the eNOS/NO/cGMP/PKG pathway [95,98]; the NO production by the beans agglutinin can reduce the platelet aggregation, explaining the lower platelet activation compared with agglutinin from whole grain [99].

Many components from Phaseolus can help with the regulation of platelet aggregation as glycine by impeding the calcium influx [100], arginine by enhancing the nitric oxide activity in hypercholesterolemic patients [101], or anthocyanin by inhibiting the plateletmonocyte and platelet-endothelial interaction [102].

Derivatives of alpha-linoleic acid can inhibit platelet aggregation and inflammation, which has been linked to the prevention of CVD, hypertension, type 2 diabetes, chronic obstructive pulmonary disease, among others [19]. Especially, the role of omega3 and omega6 has been discussed many times for his role in platelet aggregation; many papers report the inhibitory effect of omega3 in ADP-dependent platelet aggregation [103,104], with a noticeable effect in healthy patients, unlike CVD patients who had a low increase in lag time [105]. Meanwhile, high omega 6 levels have been related to pro-inflammatory and pro-aggregatory phenotypes [106], by increasing the susceptibility of LDL to oxidate and therefore increasing the TXA2 production [107].

\subsection{Effect on the Endothelium}

The ingestion of inadequately cooked beans can result in severe glycemic index tract distress; the proposed mechanism of damage prevents the repair of the epithelial cell surface disruptions, resulting in necrotic cell death. The lectins are known to inhibit the exocytosis event required to repair the plasma membrane, and that is the mechanism used to maintain and accumulate the damage in the GI tract [108].

As we discussed, the common bean is cultivated worldwide and used as a nutraceutical food, when cooking properly, but is not the only process used to gain nutritional value from these pulses. The common bean hydrolysate had reported many effects from angiotensin-converting enzyme inhibitor to antioxidant, antimicrobial, and even tumor cell inhibitor. The bioactive potential of peptides present in the indigestible fraction of com- 
mon beans that protect cells from oxidative stress and inhibit the angiotensin-I converting enzyme by interacting with its catalytic cavity independently of its antioxidant capacity was demonstrated [109].

Gomes et al. explained the hydrolysate capacity to modulate lipid metabolism and prevent endothelial dysfunction in BALB/c mice; they also showed hypocholesterolemic activity helping to reduce inflammation, oxidative stress, and endothelial dysfunction [110]. Phaseolus vulgaris L. agglutinin (PHA) evidenced specific cytoplasmic staining of macrophages in rabbit vessels, monkeys, and human tissues (atherosclerotic arteries obtained in surgery). When analyzing the morphometric comparisons between PHA staining of the lesion and acid lipase as a macrophage marker, similar results were obtained. In this context, they concluded that PHA is an excellent experimental marker to differentiate and quantify macrophages in fixed and human atherosclerotic lesions [111]. The use of hydrolysates of Phaseolus vulgaris shows an interesting effect in mice, from the modulation of the lipid profile to the increase in e-NOS expression [110]; this effect can be explained by the effect of the compounds found in the bean, upon endothelial cells. This is the case of n-3 PUFAs such as omega3 that, in trials, have shown prevention of endothelial dysfunction [112], or of amino acids such as lysine, leucine, serine and glutamine that work as modulators of NO production [113].

\subsection{Effect on Inflammation}

Some studies have focused on evaluating the effect of different plants with beneficial effects on pro-inflammatory mechanisms, mainly to reduce cardiovascular risk factors [114] Macrophages are the main source of pro-inflammatory cytokines and can be used as markers of chronic inflammation, tumor necrosis factor $\alpha$ (TNF- $\alpha$ ), interleukins (IL), and prostaglandins E-2 (PGE-2), among others. TNF- $\alpha$ plays a fundamental role in the expansion of the inflammatory process since it induces the production of IL-1 $\beta$, among other pro-inflammatory cytokines [115], and increases PGE-2 [116,117].

Peroxisome Proliferator-Activated Receptors (PPARs) are transcription factors that belong to the superfamily of ligand-activated nuclear receptors, which mainly regulate lipid metabolism [118]. PPAR- $\alpha$ ligands are known to have anti-inflammatory effects in various cells through apoptosis in cytokine-activated macrophages, inhibiting NFKB signaling $[118,119]$. It has been described that the enzymatic hydrolysis of beans produces protein hydrolysates with anti-inflammatory activity [120] that could counteract the chronic inflammatory process initiated by human macrophages [117]. Research highlights the effectiveness of total digested proteins and peptides from bean seeds against adipogenic complications and inflammation [121]. Hydrolysate protein from this legume has been shown to decrease inflammation in adult male mice fed an atherogenic diet for nine weeks [110].

Phaseolin is the main globulin reserve in bean seeds [67]. This protein is a potential therapeutic candidate for the management of inflammation. Phaseolin inhibits nitric oxide production; inducible nitric oxide synthase expression also suppresses pro-inflammatory mediators such as cyclooxygenase 2 (COX-2), interleukin- $1 \beta$ (IL- $1 \beta)$, tumor necrosis factor $\alpha(\mathrm{TNF}-\alpha)$, among others [122].

Oseguera et al. evaluated the antioxidant capacity of protein hydrolysates (rich in bioactive peptides derived from phaseolin) from the Negro 8025 and Pinto Durango varieties of Phaseolus vulgaris L. and determined their effect on the markers of inflammation in RAW 264.7 macrophages induced by lipopolysaccharides. Durango Pinto bean alcalase hydrolysates at 120 min inhibited inflammation (inhibition of cyclooxygenase (COX)-2 expression, prostaglandin $\mathrm{E}_{2}$ production, inducible nitric oxide synthase (NOS) expression, and NO production) to a greater extent than black beans. Additionally, the hydrolysates inhibited the transactivation of NF- $\mathrm{kB}$ and the nuclear translocation of the p65 subunit of NF-kB [120]. 
Kim et al., 2016, studied the effects of adzuki beans on lipid accumulation and inflammation mediated by oxidative stress in male C57BL mice induced by a diet high in cholesterol and fat for 6 weeks. The results suggested that adzuki beans decrease lipid accumulation and inflammation induced by oxidative stress, by a mechanism of suppression of hepatic messenger RNA expression of lipogenic and inflammatory mediators. This effect could be associated with the rich anthocyanin, catechin, and saponin content of adzuki beans [123].

The effect of whole wheat flour and bean protein hydrolysate from the common bean variety Carioca on inflammation and oxidative stress was studied in BALB mice fed a diet high in fat and cholesterol. Animals fed whole bean meals showed less weight gain, higher levels of alanine aminotransferase, and low-density lipoprotein cholesterol than animals fed bean protein hydrolysate. The expression of PPAR- $\alpha$ was lower in the groups fed with bean protein hydrolysate and bean flour. These results could be associated with the increase in inflammation generated in diet-induced obesity since a short period was sufficient to decrease the inflammatory marker (PPAR). The positive effect on inflammation is attributable to phenolic compounds such as catechin and kaempferol present in bean flour, while in the protein hydrolysate; it is attributed to biologically active peptides and proteins such as phytohemagglutinin, alpha and beta phaseolin, alpha-amylase 1 inhibitor, and alpha-amylase 2 inhibitors [119,124].

Another study refers to how postharvest storage time influences the inflammation of Carioca, Madreperola, and Pontal beans, stored (0,3, and 6 months), cooked, and subjected to simulated gastrointestinal digestion with pepsin-pancreatin. The study was conducted in human THP-1 macrophage-like cells. The commercial storage time did not affect the protein concentration, the degree of hydrolysis, the hydropathic, or the antioxidant capacity. All hydrolysates reduced TNF- $\alpha$ by about $30 \%$. The Madreperola hydrolysates decreased IL-1 $\beta$ and PGE-2. Carioca beans inhibited inflammation due to their content of bioactive peptides and phenolic compounds, and it was shown that the commercial storage time did not affect the physicochemical or biological properties [117].

Studies have shown that the antioxidant and anti-inflammatory activities of bean extracts are associated with polyphenols present capable of inhibiting COX and lipoxygenase (LOX). Acetone extract made from black bean peel exhibited strong inhibitory effects of COX-1 $\left(\mathrm{IC}_{50}=1.2 \mu \mathrm{g} / \mathrm{mL}\right)$ and COX-2 $\left(\mathrm{IC}_{50}=38 \mu \mathrm{g} / \mathrm{mL}\right)$, while the aqueous extracts were stronger inhibitors of lipoxygenase, $15-\mathrm{LOX}$, versus the acetone extracts. The COX and LOX inhibitory activities of aqueous extracts such as acetone suggest that the use of bean shells in food may protect against some diseases associated with chronic inflammation [125]. People who consume beans and whole grains have been found to have a longer life expectancy and lower burden of chronic diseases, including obesity, CVD, diabetes, and cancer [126], which are characterized by having a strong chronic inflammatory component [127].

\subsection{Effect on Metabolic Syndrome}

Metabolic syndrome (METS) is a simultaneous group of metabolic disorders that includes central obesity (abdomen), insulin resistance, hypertension, glucose intolerance, and dyslipidemia [128], which increases the risk of CVD. It is estimated that it affects almost $35 \%$ of the US adult population, and its prevalence increases with age [129].

A healthy lifestyle, improving eating habits, and physical activity, are the therapeutic recommendations for the treatment and management of METS, but a gold standard dietary pattern for its management has not yet been proposed [130]. In this sense, many researchers have pointed out that a diet high in unsaturated fats, (olive oil), together with the consumption of legumes, cereals (whole grains), fruits, vegetables, nuts, fish, and low-fat dairy products, can prevent and delay the development of METS and prevent CVD [131].

One of the main causes of the development of this chronic syndrome is an imbalance between caloric consumption and expenditure. METS is associated with excessive activity of glucose metabolism enzymes and inflammatory processes [132]. Thus, a diet with low glycemic index products, such as Phaseolus vulgaris L., slows down the absorption 
of carbohydrates due to the inhibition of alpha-amylase and glucosidase enzymes, been proven in clinical trials [133].

Products that slow the absorption of carbohydrates by inhibiting the enzymes responsible for their digestion have been described as a powerful alternative to achieving a low-glycemic diet. These products include alpha-amylase and glucosidase inhibitors, which can reduce the risk of diabetes and heart disease and its complications. The common white bean (Phaseolus vulgaris L.) inhibits alpha-amylase by the action of the alpha-amylase inhibitor protein $(\alpha \mathrm{AI})$, which has been characterized and demonstrated in various clinical studies, demonstrating the ability of beans to cause weight loss (doses between 500 to $3000 \mathrm{mg}$ per day). Conversely, the ability of this legume to reduce the postprandial peak in blood glucose levels depending on the dose has also been pointed out $[133,134]$. Common beans have three isoforms of alpha-amylase inhibitors (alpha-A1, alpha-A12, alpha-AIL). The alpha-AI isoform has anti-amylase activity in humans. This enzyme is only found in the embryonic axes and cotyledons of the plant seed. The alpha-amylase inhibitor prevents starch assimilation by completely blocking access to the active site of the enzyme. Some factors that affect the activity of the alpha-AI isoform inhibitor are $\mathrm{pH}$, temperature, incubation time, and the presence of particular ions. Several authors have pointed out that the common bean reduces the rate of carbohydrate absorption, thus reducing the glycemic index of foods, as well as weight loss when consumed at the same time with carbohydrate-containing meals [133].

The consumption of legumes such as Phaseolus vulgaris L. provides bioactive molecules with an effect on obesity and metabolic syndrome, mainly due to a decrease in weight and triglyceride levels, although more quality trials must be performed to establish clinical efficacy [135]. In this sense, overweight individuals who received Phaseolus vulgaris L. extract had a significantly greater reduction in body weight index, fat mass, adipose tissue thickness, and anthropometric measurements of waist, hip, and thigh compared to the placebo group. The authors point out that this effect is based on the activity of $\alpha$ AI described in the extracts of Phaseolus vulgaris [136]; furthermore, the daily consumption of baked beans (Phaseolus vulgaris L.) for 14 days as part of a regular diet significantly decreased the mean total plasma cholesterol level of the volunteers: from 5.1 to $4.5 \mathrm{mmol} / \mathrm{L}(p<0.02)$ [137]. This is correlated with the effect of dry beans, where it was identified that they reduce serum lipid concentrations in healthy and hyperlipidemic subjects, specifically serum cholesterol and triglyceride concentrations by $10.4 \%(p<0.001)$ and $10.8 \%(p<0.025)$, respectively, along with reducing body weight, despite constant energy intake, contributing to the management of hyperlipidemia present in METS due to its high content of soluble fiber, which alters the absorption of lipids in the intestine, affecting the synthesis of cholesterol to hepatic level [138].

In a clinical trial with 12 adults diagnosed with METS who ate one of three meals: black beans (BB), combined fiber (FM), and combined antioxidant capacity (AM), it was found that in the group that consumed black beans, postprandial insulinemia was lower after the meal compared to the other groups $(p<0.0001)$, and there was an improvement in plasma antioxidant capacity $(p=0.002)$, which could be explained by the fiber content of beans [139]. Similar effects were seen in healthy individuals, where consumption of Phaseolus vulgaris L. extract reduced postprandial glucose, insulin, and increased satiety [140]. Finally, 12 volunteers with METS were given in three different meals: no added fiber (control (NF), extrinsic or added fiber (AF), or whole black beans as a source of intrinsic fiber (BN). The BN meal produced a significant reduction in comparison with controls $(p<0.0001)$, showing beneficial effects in patients with METS [141]. In the context of animal models, in METS-induced male C57BL/ 6 mice, Phaseolus vulgaris L. extract reduced body weight and effectively lowered blood glucose, triglycerides, and cholesterol. At the same time, histological analysis of the aorta showed protection against the development of fatty streaks in the muscle layers. The authors conclude that the mechanism of action is due to the presence of $\alpha \mathrm{AI}$ and alpha-glucosidase inhibitors [142]. In another investigation, 
treatment with a combination of Phaseolus vulgaris L. and Cynara scolymus extracts reduced food intake and blood glucose in rats [143].

Proteins are abundant components in beans. The positive effect on blood pressure reduction of bean protein hydrolysates has been reported in hypertensive rats, which is attributed to the ability of peptides to inhibit angiotensin-converting enzyme (ACE) $[110,144]$. Glutelin hydrolysates show a potent ACE inhibitory activity of around $80.24 \%$. The results show that glutelin could be an effective hypertensive in ACE [145]. Conversely, the administration of a black bean protein hydrolysate at a concentration of $200 \mathrm{mg} / \mathrm{kg}$ showed a hypoglycemic effect in rats $[110,146]$. Studies have highlighted that starch-enriched diets lower cholesterol levels, improving dyslipidemia and body composition. A double-blind, placebo-controlled crossover intervention showed that individuals who consumed a diet rich in starch for 12 weeks show favorable results for the promotion of these diets in public cardiometabolic health [147]. Another study examined the effect of starch on hypolipidemic actions, blood glucose, insulin levels, and humoral immune responses in healthy, overweight subjects who were fed $24 \mathrm{~g}$ /day of resistant cornstarch or regular cornstarch for 21 days. Reducing effects of total serum cholesterol and serum LDL cholesterol were evidenced. These results suggest that starch supplementation improves blood lipid profile and controls blood glucose levels in healthy overweight subjects [148].

Many studies suggest the effect of linoleic acid on obesity, cancer, atherosclerosis, among other health benefits. Linoleic acid has been shown to promote fat loss in rodent models [149]. Initial studies in male and female mice showed that a mixed diet supplemented with conjugated linoleic acid promotes fat loss by $60 \%$ for 30 days; this effect was attributed to increased lipolysis and fat oxidation [149,150]. Recently, it has been recognized that supplementation with this acid reduces fat stores, and dramatically decreases circulating adiponectin levels in mice $[149,151]$.

Evidence suggests that the consumption of derivatives of Phaseolus vulgaris L. reduces food intake, body weight, lipid deposition, and blood glucose in rats due to the inhibition of $\alpha$-amylase, reducing carbohydrate metabolism [152]. Together, these data in animal models and clinical trials demonstrate the potential effect of Phaseolus vulgaris L. to treat obesity and METS, consecutively decreasing the development of thrombotic events.

\subsection{Effect of Beans on Atherosclerosis}

Studies have shown that diet attenuates atherosclerosis, the mechanisms of which are related to less atherogenic dyslipidemia, relief of intestinal dysbiosis, and suppressed inflammation [153]. The atherosclerotic process is established from the increase of proatherogenic and pro-inflammatory mediators that favor plaque formation and progressive stenosis $[154,155]$. The initial step of atherosclerosis is associated whit high levels of lowdensity lipoproteins (LDL), oxidation of LDL, and recruitment of monocytes [155,156]. The accumulation of cholesterol-laden macrophage foam cells is a key feature of atherosclerotic lesions. Cholesterol can enter macrophages through various pathways and induce the transformation of macrophages into foam cells [157].

Studies have shown that beans can improve lipid profiles associated with the development of atherosclerotic lesions and the prevalence of CVD. Consuming beans lower cholesterol without affecting serum triglycerides, VLDL cholesterol, or blood glucose [158]. Oxidized LDL (ox-LDL) and its interaction with the ox-LDL lectin receptor (LOX-1) determine the progression of atherosclerosis. Peptides from carioca beans have shown antiatherosclerotic properties comparable to simvastatin, through inhibition of LOX-1, MMP-9, and ICAM-1 and inhibition of 10 cytokines related to the atherosclerotic process (128). Research shows that chia, a variety of beans, is considered a good source of dietary fiber, protein, antioxidants, and bioactive lipids $[159,160]$. In recent years, chia seeds have gained great importance due to their high alpha-linolenic acid content $(68 \%)$ and their relationship to human health and nutrition [161]. 
Various studies have indicated that this compound has cardioprotective properties by affecting specific biomarkers (lactate dehydrogenase; LDH) [162]. The background shows that conjugated linoleic acid has the potential to inhibit cholesterol-induced atherosclerosis in rabbits and hamsters, respectively [163]. Conjugated linoleic acid inhibits experimentally induced atherosclerosis in rabbits fed an atherogenic diet. A reduction in pre-established atheromatous lesions was evidenced [164]. Conjugated linoleic acid reduced early aortic atherosclerosis to a greater extent than linoleic acid in a hypercholesterolemic hamster population. These effects may be related to changes in the oxidative susceptibility of LDL in hypercholesterolemic hamsters [165].

The intake of dietary fiber has been associated with an inhibition of the development of atherosclerosis in animal models [88], while soluble fiber reduces serum cholesterol and LDL cholesterol concentrations [88,166]. In general, proteins of animal origin are more cholesterolemias and atherogenic than proteins of plant origin [167]. Research has highlighted that the oral administration of peptides synthesized from amino acids reduces atherosclerosis independently of plasma cholesterol in a group of mice, thus improving the capacity of high-density lipoproteins (HDL) in the study population [168]. Specific studies with different varieties of beans have shown that the consumption of this legume reduces $10 \%$ of the cholesterol levels of normal young men after ingestion of $450 \mathrm{~g} / \mathrm{d}$ of canned baked beans compared to the control group [137]. A 10\% reduction in serum cholesterol levels was also reported in hyperlipidemic men fed 120-162 g/d of pinto beans [138].

Celleno et al. showed that overweight subjects who consumed a dietary formula with Phaseolus vulgaris L. extract as the main ingredient, significantly decrease body fat due to the interference caused by this legume in the digestion of carbohydrates, thus contributing to the prevention of atherosclerosis by reducing fats in organs and tissues [136]. Phaseolus vulgaris L. provides micronutrients, particularly folic acid and magnesium, and its high content of fiber, sulfur amino acids, tannins, phytoestrogens, and non-essential amino acids have been linked to the prevention of atherosclerotic lesions. The prevention of atherosclerosis is a powerful tool in the prevention of cardiovascular events, as this silent pathology is responsible for about half of deaths from heart disease $[19,169]$.

\subsection{Other Studies Related to Cardioprotective Role}

The intake of Phaseolus vulgaris L. has been decreasing during the last decades, which has coincided with an increase in the incidence of chronic diseases such as obesity and CVD [170]. Epidemiological studies show that the consumption of legumes is inversely associated with the risk of coronary heart disease, type II diabetes mellitus, and obesity; specifically, the intake of beans is associated with the reduction of risk factors by regulating glycemia and normalizing the lipid profile in the blood [171]. Researchers point out that it is possible to reduce the incidence of coronary heart disease with diet [172] and that the consumption of beans reduces the risk of ischemic heart disease and CVD [170].

Some studies show that bioactive molecules such as the phenolic compounds of Phaseolus vulgaris L. are associated with a protective effect against CVD, diabetes, and cancer; due to their antioxidant and anti-inflammatory properties $[173,174]$. Those who have a diet that includes Phaseolus vulgaris L. bean species have a lower prevalence of diabetes, CVD, and cancer [175]. The cardioprotective effect of beans is associated with its content of kaempferol and catechin, which lower cholesterol levels, use HDL levels, and inhibit lipid peroxidation [176]. This effect was reflected in a clinical trial, where the consumption of a cup of beans, decreased LDL levels after 6 hours when compared with the control (consumption of rice). In addition, a positive effect was generated on the tension properties of the blood vessels, favoring vascular function [177].

In an in vitro study, the extract of hardened common bean residue (composed of a peptide fraction $<3 \mathrm{kDa}$ (PV3)) reduced ROS levels and increased $\mathrm{NO}$ in the endothelium, favoring vasodilation and showing a therapeutic potential [178]. Along the same lines, bean extracts significantly decreased the percentage of platelet aggregation in plateletrich plasma, induced by adenosine $5^{\prime}$-diphosphate (ADP) and arachidonic acid, along 
with decreasing activation markers expressed in the platelet membrane (P-selectin). This supports the hypothesis that common beans reduce the risk of CVD by reducing platelet activation processes that initiate thrombus formation [92].

In animal models, Sprague-Dawley rats and a diet-induced obesity model in C57Bl/6 mice were used to evaluate the effect of cooked dry beans; in both animal species, shortterm feeding decreased total plasma cholesterol and LDL cholesterol after 14 days [179]. In this context, the incorporation of extruded beans into the diet of obesogenic rats reduced the levels of cholesterol and liver triglycerides $(p<0.001)$ and low-density lipoproteins (LDL; $p<0.01$ ), favoring metabolism of lipids [180]. These results together show a cardioprotective effect of Phaseolus vulgaris L.

Additionally, studies have shown that a low glycemic index diet reduces the risk of cardiovascular events. Nourí et al. showed that a population of around 5000 subjects who consumed legumes as the main food decreased the occurrence of CVD by around 34\%, including fatal and non-fatal myocardial infarction, unstable angina, fatal and non-fatal stroke, and death sudden cardiac arrest. This study indicated an inverse relationship between legume intake and the risk of CVD in elderly people [63].

The intake of fatty acids, dietary fiber, and antioxidant compounds reduce the risk of heart disease $[88,181,182]$. Epidemiological studies suggest that the high intake of complex carbohydrates and dietary fiber is directly related to the decrease in coronary artery disease [88,183]. Beans provide all these nutrients with cardioprotective properties to our diet.

Additionally, diets enriched with polyunsaturated fatty acids such as omega-3 show promise in the primary and secondary prevention of CVD. Studies have been encouraging, showing positive results for in vivo trials in preventing myocardial infarction and heart failure [184]. Omega-3 can prevent fatal arrhythmias through the inhibition of sodium and calcium channels $[184,185]$. One study found an inverse association between the intake of baked or roasted fish and heart failure in 4738 men and women [184,186]. Another 13-year investigation revealed the beneficial effects in preventing CVD mortality of a diet rich in omega-3 of a Japanese population [184,187]. Conversely, dietary supplementation with B vitamins or omega-3 fatty acids, or both, could prevent major cardiovascular events in patients with a history of ischemic heart disease or stroke [188].

Table 1 shows the compounds identified in P. vulgaris with a history of cardioprotective potential. This analysis could promote the consumption of this legume considering that it could have a beneficial effect on several CVD risk factors. It has been shown that certain components of the diet can reduce blood platelet activation and have an important influence on the prophylaxis and treatment of cardiovascular disorders [2].

Table 1. Cardioprotective studies of bioactive compounds from Phaseolus vulgaris L.

\begin{tabular}{|c|c|c|}
\hline Compound & Classification & Mechanisms \\
\hline \multirow{5}{*}{ Coumaric acid } & \multirow{5}{*}{ Phenolic acid } & $\begin{array}{l}\text { Reduces ADP-induced platelet aggregation in vitro. Modifies platelet function, } \\
\text { measured with PFA-100 }(500 \text { and } 1 \mu \mathrm{M}) \text {. } \\
\text { Mechanism: inhibits the AA cascade, reducing TxA2 production and the generation of } \\
\text { prostaglandin } \mathrm{E}_{2} \text { induced by lipopolysaccharides }\left(\mathrm{IC}_{50}: 371 \text { and } 126 \mu \mathrm{M}\right)[189] \text {. } \\
\text { Inhibits ADP-induced platelet aggregation in vivo without affecting blood coagulation. } \\
\text { Mechanism: associated with a marked increase in plasma antioxidant activity, measured } \\
\text { as plasma iron-reducing capacity, and with a reduction in TxA2 production [189]. }\end{array}$ \\
\hline & & $\begin{array}{c}\text { Reduces apoptosis in vivo in rats with isoproterenol-induced myocardial infarction by } \\
\text { inhibiting oxidative stress }(2.4 \text { and } 8 \mathrm{mg} / \mathrm{kg}) \text {. } \\
\text { Mechanism: protective effect due to anti-lipid peroxidative, antioxidant, and } \\
\text { anti-apoptotic properties [190]. }\end{array}$ \\
\hline & & Inhibits in vitro TRAP-induced surface P-selectin expression $(100 \mu \mathrm{mol} / \mathrm{L})$ [191]. \\
\hline & & $\begin{array}{l}\text { Inhibits in vivo LDL oxidation and decreases MDA production, causing a decrease in } \\
\text { atherosclerosis }(100 \mathrm{mg} / \mathrm{kg}) \text { [192]. }\end{array}$ \\
\hline & & Protects the heart in vivo against DOX-induced oxidative stress $(100 \mathrm{mg} / \mathrm{kg})$ [193]. \\
\hline
\end{tabular}


Table 1. Cont.

\begin{tabular}{|c|c|c|}
\hline Compound & Classification & Mechanisms \\
\hline \multirow{3}{*}{ Chlorogenic acid } & \multirow{3}{*}{ Phenolic acid } & $\begin{array}{l}\text { Inhibits in vitro platelet secretion and aggregation induced by ADP, collagen, AA, and } \\
\text { TRAP-6. Decreases platelet adhesion, aggregation, and platelet-leukocyte interactions } \\
\text { under flow conditions. Inhibits platelet inflammatory mediators (P-selectin, sCD40L, } \\
\text { CCL5, and IL-1 } \beta) \text { and increases intra-platelet cAMP levels by activation of PKA } \\
\text { ( } 0.1 \text { to } 1 \mathrm{mmol} / \mathrm{L}) \text {. }\end{array}$ \\
\hline & & Mechanism: adenylate cyclase/cAMIP/PKA receptor signaling pathway [194]. \\
\hline & & $\begin{array}{l}\text { Inhibits collagen-induced platelet aggregation and suppresses TxA2 production, } \\
\text { associated with COX-1 inhibition in platelet microsomes that have activity on } \\
\text { cytochrome c reductase. Increases the formation of cAMP and cGMP and intracellular } \\
\qquad \mathrm{Ca}^{2+}(10,30 \text {, and } 50 \mathrm{mmol} / \mathrm{L}) \text {. } \\
\text { Mechanism: reduction of TxA2 and increased levels of cAMP and cGMP [195]. }\end{array}$ \\
\hline \multirow[b]{3}{*}{ Ferulic acid } & \multirow[b]{3}{*}{ Phenolic acid } & $\begin{array}{l}\text { Inhibits in vitro the expression of P-selectin on the surface induced by TRAP } \\
(100 \mu \mathrm{mol} / \mathrm{L}) \text {. Inhibits platelet aggregation induced with collagen } 3.5 \mu \mathrm{g} / \mathrm{mL} \\
\qquad(100 \mu \mathrm{mol} / \mathrm{L})[191] .\end{array}$ \\
\hline & & $\begin{array}{l}\text { Inhibits in vitro platelet aggregation stimulated with ADP } 8 \mu \mathrm{mol} / \mathrm{L} \text { and collagen } \\
\qquad 1.5 \mu \mathrm{g} / \mathrm{mL}(0.5 \mathrm{mmol} / \mathrm{L})[196] .\end{array}$ \\
\hline & & $\begin{array}{l}\text { Protects in vivo death produced by pulmonary thrombosis and prolongs tail bleeding } \\
\text { time in mice and rats }(20,40 \text {, and } 80 \mathrm{mg} / \mathrm{kg} \text { for mice, or } 10,20 \text {, and } 40 \mathrm{mg} / \mathrm{kg} \text { for rats). } \\
\text { Inhibits in vitro platelet aggregation induced by ADP, thrombin, collagen, and AA. It } \\
\text { decreases the mobilization of intracellular } \mathrm{Ca}^{2+} \text { and the production of TxA2. Increases } \\
\text { levels of cAMP and cGMP and phosphoprotein stimulated by VASP while decreasing } \\
\text { phospho-MAPK and PDE (200 mM). } \\
\text { Mechanism: activation of cAMP and cGMP signaling [197]. }\end{array}$ \\
\hline
\end{tabular}

Synapic acid Phenolic acid
Inhibits in vitro platelet aggregation and coagulation with antithrombotic effect $(0.25$ $\mathrm{mg} / \mathrm{mL}, \mathrm{IC}_{50}: 1.03 \mathrm{mM}$ ) [198].

Decreases in vitro SIPA and attenuates platelet activation, intracellular $\mathrm{Ca}^{2+}$ mobilization, granule secretion, and adhesion receptor expression $(10-25 \mu \mathrm{M})$.

Mechanism: blockade of the binding of VWF to activated GPIb, primary and initial event for the performance of SIPA [199].

Reduces myocardial infarction size, serum TNF- $\alpha$ levels, and platelet aggregation in vitro. Inhibits apoptosis and caspase- 3 expression and positively regulates phosphorylated Akt expression in cardiomyocytes subjected to injury by $\mathrm{H} / \mathrm{R}(250-500 \mathrm{mg} / \mathrm{kg})$.

Protocatechic acid Phenolic acid Mechanism: provides protection against MI/R injury, inflammatory response, platelet aggregation, and apoptosis of cardiomyocytes [200].

Inhibits platelet apoptosis induced by decreased dissipation of mitochondrial membrane potential, activation of caspase- 9 and caspase- 3 , and decreased exposure to PS. Modulates the distributions of $\mathrm{Bax}, \mathrm{Bcl}-\mathrm{xL}$, and cytochrome $\mathrm{c}$ mediated by $\mathrm{H}_{2} \mathrm{O}_{2}$ in mitochondria and cytochrome. It decreases ROS generation and intracellular $\mathrm{Ca}^{2+}$ concentration, caspase- 3 signaling and activation, and PS exposure $(0.5$ or $1 \mu \mathrm{M})$. Mechanism: protects platelets from oxidative stress-induced apoptosis by regulating ROS-mediated PI3K/Akt/SK3 $\beta$ signaling [201].

Inhibits clotting factors, decreases the secretion of dense granules, and retraction of the clot. Regulates the downstream signaling pathway of DEP-1/PTP-1B / $\alpha \mathrm{Ilb} \beta 3 /$ kinases. It decreases the expression of density-enhanced phosphatase-1 (DEP-1)/protein tyrosine phosphatase-1B (PTP1B) $/ \alpha \operatorname{Ilb} \beta 3$, as well as the phosphorylation of platelet kinases stimulated with collagen/epinephrine both in vitro and in vivo $(5,10$ and $20 \mu \mathrm{g})$. It inhibits the secretion of granular components, clot retraction, and $\mathrm{FeCl}_{3}$-induced vascular occlusion of the carotid artery.

Syringic acid Phenolic acid

Mechanism: attenuates the development of thrombosis and thromboembolism by inhibiting fibrin, clot formation, clotting factors, and platelet stimulation through 
Table 1. Cont.

\begin{tabular}{|c|c|c|}
\hline Compound & Classification & Mechanisms \\
\hline \multirow{4}{*}{ Myricerin } & \multirow{4}{*}{ Flavonoid } & $\begin{array}{l}\text { Reduces the ability of platelets to spread on collagen and form thrombi in vitro without } \\
\text { affecting hemostasis in vivo. Inhibits the activities of PDI and ERp5 reductase }(10,30 \text {, } \\
\text { or } 100 \mu \mathrm{M}) \text {. } \\
\text { Mechanism: ERp5 and PDI inhibitor [203]. }\end{array}$ \\
\hline & & $\begin{array}{l}\text { Inhibits in vitro PAF-induced platelet adhesion }\left(\mathrm{IC}_{50}: 13.1 \mathrm{mmol} / \mathrm{L}\right) \text { and internal free } \\
\mathrm{Ca}^{2+} \text { concentration. It inhibits platelet aggregation PAF } 1,2 \text {, and } 4 \mathrm{nmol} / \mathrm{L} \text { with } \mathrm{IC}_{50}: \\
34.8,85.7 \text {, and } 118.6 \mathrm{mmol} / \mathrm{L} \text {. Mechanism: antagonizes the specific binding of the } \\
\text { PAF receptor [204]. }\end{array}$ \\
\hline & & $\begin{array}{c}\text { Inhibits in vivo } 3.6 \mu \mathrm{g} / \mathrm{kg} \text { cat blood platelet aggregation. Reduces platelet thrombi } \\
\text { in vitro at a concentration of } 60 \mathrm{nM} \text {. } \\
\text { Mechanism: inhibits } \mathrm{PGI}_{2} \text { synthase [205]. }\end{array}$ \\
\hline & & $\begin{array}{l}\text { Inhibits platelet aggregation. Increases the cAMP stimulated by } \mathrm{PGI}_{2} \text {. Inhibits } \\
\text { lipoxygenase activity }(50 \mu \mathrm{M}) . \\
\text { Mechanism: modification of cAMP metabolism through inhibition of } \\
\text { phosphodiesterase activity [206]. }\end{array}$ \\
\hline \multirow{4}{*}{ Genistein } & \multirow{4}{*}{ Isoflavonoid } & $\begin{array}{l}\text { Inhibits in vitro human platelet aggregation, serotonin secretion, and phosphorylation } \\
\text { of protein tyrosine induced by collagen and TxA2. It slightly attenuates } \\
\text { thrombin-induced protein tyrosine phosphorylation }(100 \mu \mathrm{g} / \mathrm{mL}) . \\
\text { Mechanism: preventive action on TxA2 binding, through inhibition of protein } \\
\text { tyrosine phosphorylation [207]. }\end{array}$ \\
\hline & & $\begin{array}{l}\text { Inhibits in vitro dose-dependent collagen-induced platelet aggregation, NO production, } \\
\text { and TNF- } \alpha \text { secretion. Decreased secretion of MCP-1 induced by TNF- } \alpha \text { in endothelial } \\
\text { cells of the human umbilical vein }(50 \mu \mathrm{M}) . \\
\text { Mechanism: through TNF- } \alpha \text { [208]. }\end{array}$ \\
\hline & & $\begin{array}{l}\text { Inhibits platelet aggregation or the release of serotonin-induced by thrombin and } \mathrm{Ca}^{2+} \text {. } \\
\text { Inhibits the COX pathway and } \mathrm{PI} 3 \text { and } \mathrm{PI}(4,5) \mathrm{P} 2(50 \mu \mathrm{M}) \text { production. } \\
\text { Mechanism: acts on the passage of inositol phospholipids [209]. }\end{array}$ \\
\hline & & $\begin{array}{c}\text { Decreases PAF stimulation of PLC activity at baseline. Inhibits PAF-stimulated platelet } \\
\text { aggregation. Inhibits PI3 production and reduces induced phosphorylation }(0.5 \mathrm{mM}) \text {. } \\
\text { Mechanism: inhibits tyrosine kinase early in signal transduction by inhibiting PLC. } \\
\text { Decreases the activation of PKC and causes a reduction in } \\
\text { protein phosphorylation [210]. }\end{array}$ \\
\hline Glycythein & Isoflavonoid & $\begin{array}{l}\text { Inhibits proliferation and synthesis of SMC DNA induced by PDGF-BB }(3-10 \mu \mathrm{mol} / \mathrm{L}) \text {. } \\
\text { Mechanism: inhibitory effect on SMC proliferation attenuates said proliferation (basic } \\
\text { mechanism involved in atherosclerotic vascular change) [211]. }\end{array}$ \\
\hline \multirow{3}{*}{ Formononetin } & \multirow{3}{*}{ Isoflavonoid } & $\begin{array}{l}\text { Inhibits ferric chloride-induced arterial thrombus formation in rats and ADP- and } \\
\text { thrombin-stimulated platelet aggregation in rats. Prolongs bleeding time and aPTT in mice } \\
\text { Mechanism: inhibits platelet aggregation induced by ADP and thrombin and reduces } \\
\text { the function of the endogenous clotting pathway [212]. }\end{array}$ \\
\hline & & $\begin{array}{l}\text { Inhibits PDGF-BB-induced proliferation and migration of human VSMCs. Inhibits } \\
\text { upregulation of cell cycle-related proteins, matrix metalloproteinase, and } \\
\text { PDGF-BB-induced phosphorylation of AKT in VSMC }(1 \mu \mathrm{M}) \text {. } \\
\text { Mechanism: suppressive effect on PDGF-BB-stimulated proliferation and migration of } \\
\text { VSMC, through inhibition of the AKT signaling pathway [213]. }\end{array}$ \\
\hline & & $\begin{array}{l}\text { Increases cell migration, tube formation, and levels of PECAM-1 and VEGF and platelet } \\
\text { endothelial cells of the human umbilical vein. Protects against cerebral ischemia and } \\
\text { reperfusion injury in rats. Improves cerebrovascular angiogenesis in human umbilical } \\
\text { vein endothelial cells (10 and } 20 \mu \mathrm{g} / \mathrm{mL}) \text {. } \\
\text { Mechanism: suppresses cell apoptosis and improves cerebrovascular angiogenesis by } \\
\text { promoting the expression of VEGF and PECAM-1 [214]. }\end{array}$ \\
\hline
\end{tabular}


Table 1. Cont.

\begin{tabular}{|c|c|c|}
\hline Compound & Classification & Mechanisms \\
\hline Naringenin & Flavanone & $\begin{array}{l}\text { Decreases kidney failure in rats and the lipid profile. Inhibits levels of inflammation } \\
\text { markers and pro-oxidants in the kidney of rats. Moderate platelet parameters } \\
\text { (50 mg/kg/90 days). } \\
\text { Mechanism: improves kidney failure and platelet abnormalities through its } \\
\text { antioxidant effects [215]. }\end{array}$ \\
\hline \multirow[t]{2}{*}{ Hesperetin } & \multirow[t]{2}{*}{ Flavanone } & $\begin{array}{c}\text { Inhibits in vitro platelet aggregation induced with collagen } 5 \mu \mathrm{g} / \mathrm{mL} \text { and } \mathrm{AA} \\
0.5 \mu \mathrm{mol} / \mathrm{L}\left(\mathrm{IC}_{50}: 20.5 \text { and } \mathrm{IC}_{50}: 69.2\right) \text {. Collagen-induced cytosolic } \mathrm{Ca}^{2+} \text { mobilization } \\
\text { decreases from } 10 \mu \mathrm{g} / \mathrm{mL} \text { to } 20-50 \mu \mathrm{M} \text {. Inhibits collagen-stimulated serotonin secretion } \\
\text { at } \mathrm{IC}_{50}: 10.5 \text { and } \mathrm{IC}_{50}: 25.2 \text {. } \\
\text { Mechanism: inhibition of PLC } \gamma 2 \text { phosphorylation and collagen-induced } \\
\text { COX-1 activity [216]. }\end{array}$ \\
\hline & & Inhibits in vivo platelet aggregation induced with ADP and collagen (100 mg/kg) [217]. \\
\hline \multirow[t]{2}{*}{ Daidzein } & \multirow[t]{2}{*}{ Isoflavonoid } & $\begin{array}{l}\text { Inhibits in vitro dose-dependent collagen-induced platelet aggregation, NO production, } \\
\text { and TNF- } \alpha \text { secretion. Decreases secretion of MCP-1 induced by TNF- } \alpha \text { in endothelial } \\
\text { cells of the human umbilical vein }(50 \mu \mathrm{M}) . \\
\text { Mechanism: through TNF- } \alpha \text { [208]. }\end{array}$ \\
\hline & & $\begin{array}{l}\text { Inhibits proliferation and synthesis of SMC DNA induced by PDGF-BB }(3-10 \mu \mathrm{mol} / \mathrm{L}) \text {. } \\
\text { Mechanism: inhibits SMC proliferation (basic mechanism involved in atherosclerotic } \\
\text { vascular change) [211]. }\end{array}$ \\
\hline
\end{tabular}

Inhibits collagen-induced platelet aggregation and platelet adhesion to collagen (50-100 $\mu \mathrm{mol} / \mathrm{L})$.

Mechanism: inhibits platelet function by reducing the production of hydrogen peroxide and PLC [218].

Catechin Flavonol Inhibits platelet aggregation induced by AA, ADP, and Mepinephrine $(200 \mu \mathrm{g} / \mathrm{mL})$.

Decreases MDA production from AA-stimulated platelets $(20-200 \mu \mathrm{g} / \mathrm{mL})$. Mechanism: protects from peroxidative stress [219].

Ex vivo platelet function improvement in iron-loaded rats, associated with impaired antioxidant defense, including free radical-induced hemolysis $(10 \mathrm{mg} / \mathrm{kg})$. Mechanism: through normalization of antioxidant status [220].

Inhibits in vitro platelet aggregation induced with $100 \mu \mathrm{M}$ AA and $10 \mu \mathrm{g} / \mathrm{mL}$ collagen to $22 \mu \mathrm{M}$.

Inhibits ATP release stimulated with $7 \mu \mathrm{M}$ ADP and $7 \mu \mathrm{M}$ epinephrine to $25 \mu \mathrm{M}$. Mechanism: inhibits collagen $10 \mu \mathrm{g} / \mathrm{mL}$ induced TxA2 and PG formation L

Kaempferol-3glucoside

Flavonol to $5 \mu \mathrm{M}$ [221]

Inhibits in vitro platelet aggregation induced by AA $100 \mu \mathrm{M}$ and collagen $10 \mu \mathrm{g} / \mathrm{mL}$ to $100 \mu \mathrm{g} / \mathrm{mL}$ [222].

Inhibits in vitro of platelet aggregation induced with AA $150 \mu \mathrm{M}$ at $\mathrm{IC}_{50}: 24 \mu \mathrm{M}$ [206].

Inhibits the proliferation of CMLV induced by PDGF-BB 1/2) and DNA synthesis in CMLV (50 uM).

Luteolin-7 Flavone

glycoside

Mechanism: inhibits PDGF-BB 1/2 (ERK1/2)-induced extracellular signal-regulated kinase, Akt, and PLC activation [223].

Inhibits platelet aggregation and release of ATP from rabbit platelets induced by AA, collagen, ADP, PAF) and U46619 (analogous to TxA2). Inhibits degradation of phosphoinositide caused by collagen and PAF (200 uM).

Mechanism: inhibits TxA2 formation and phosphoinositide degradation [224].

Coumarin $\quad$ Benzopyrone Inhibits platelet aggregation $(25.75 \pm 4.12 \%)$. Shows the percentage of binding with GPIIb/IIIa receptor (0.5 and $2 \mathrm{mM})$ [225].

Inhibits AA-induced platelet aggregation. It does not interfere with the function of TxA2 synthase, but they were competitive antagonists of TxA2 receptors and inhibited COX-1 (50 $\mu \mathrm{M})$.

Mechanism: TxA2 stimulates its receptors on platelets, promoting platelet aggregation [226]. 
Table 1. Cont.

\begin{tabular}{|c|c|c|}
\hline Compound & Classification & Mechanisms \\
\hline Starch & Sugar & $\begin{array}{l}\text { Reduces availability of the fibrinogen receptor. } \\
\text { Mechanism: prevents the platelet from binding to fibrinogen, by blocking the access of } \\
\text { ligands to the platelet fibrinogen receptor [227]. }\end{array}$ \\
\hline \multirow{2}{*}{ Tocopherol } & \multirow{2}{*}{ Tocopherol } & $\begin{array}{c}\text { Inhibits in vitro the aggregation induced by ADP, AA, PMA. Inhibits in vivo } \\
\text { PMA-induced stimulation of PKC (400 to } 1200 \mu \mathrm{L} / \mathrm{d}) \text {. } \\
\text { Mechanism: inhibits human platelet aggregation through a } \\
\text { PKC-dependent mechanism [228]. }\end{array}$ \\
\hline & & $\begin{array}{l}\text { Inhibits platelet aggregation induced by ADP and PMA. Increases NO release, ecNOS } \\
\text { activation, and platelet protein SOD content. Decreases the activation of PKC (45 mg of } \\
\alpha \text {-tocopherol equivalents). } \\
\text { Mechanism: increased NO release, ecNOS activation, and SOD protein content } \\
\text { in platelets [229]. }\end{array}$ \\
\hline \multirow{3}{*}{ Omega- 3 and 6} & \multirow{3}{*}{ Fatty acid } & $\begin{array}{c}\text { Decreases in vivo reactivity of P2Y12 by } 22.2 \% \text {. Inhibits ADP-induced } \\
\text { platelet aggregation. } \\
\text { Mechanism: potentiates platelet response to clopidogrel then percutaneous } \\
\text { coronary intervention [230]. }\end{array}$ \\
\hline & & $\begin{array}{l}\text { Reduces in vivo thrombin formation and oxidative stress and favorably alters the } \\
\text { properties of the fibrin clot }(1 \mathrm{~g} / \text { day of PUFA } \mathrm{n}-3) \text { [231]. }\end{array}$ \\
\hline & & $\begin{array}{l}\text { Increases the total surface load of platelets and attenuates platelet activation } \\
\text { (1 to } 8 \mathrm{~g} / \text { day }) \text { [232]. }\end{array}$ \\
\hline \multirow[t]{2}{*}{ Delphinidin } & \multirow[t]{2}{*}{ Anthocyanin } & $\begin{array}{l}\text { Inhibits in vitro the secretion of alpha granules: PF4, } \beta \text {-TG, P-selectin, TGF- } \beta 1 \text {, } \\
\text { RANTES, ATP, and serotonin and CD } 63 \text { induced with thrombin } 0.5 \mathrm{U} / \mathrm{mL} \text {. } \\
\text { Inhibits the secretion of dense granules: ATP and serotonin-induced with thrombin } \\
0.5 \mathrm{U} / \mathrm{mL} \text { ( } 320 \mathrm{mg} / \text { day). } \\
\text { Mechanism: inhibits the phosphorylation of the MAPK family stimulated by thrombin } \\
0.5 \mathrm{U} / \mathrm{mL} \text {. } \\
\text { Inhibits the activation of PI3K/Akt, phosphorylation of eNOS, and production of cGMP } \\
\text { induced by thrombin } 0.5 \mathrm{U} / \mathrm{mL} \text {. } \\
\text { Inhibits in vivo the secretion of alpha granules PF4, } \beta \text {-TG, P-selectin, TGF- } \beta 1, \text { RANTES } \\
\text { stimulated with thrombin } 0.5 \mathrm{U} / \mathrm{mL}(320 \mathrm{mg} / \text { day) [233]. }\end{array}$ \\
\hline & & $\begin{array}{l}\text { Inhibits platelet aggregation induced with } 5 \mu \mathrm{M} \text { ADP, } 2 \mu \mathrm{g} / \mathrm{mL} \text { collagen, } \\
\text { and } 100 \mu \mathrm{M} \text { TRAP. } \\
\text { Inhibits in vitro the activation and secretion of P-selectin, CD63, CD40L, } \alpha \text { llb } \beta 3 \text {, and } \\
\text { fibrinogen induced with } 200 \mu \mathrm{M} \text { ADP, } 10 \mu \mathrm{g} / \mathrm{mL} \text { collagen, } 1 \mathrm{U} / \mathrm{mL} \text { thrombin, } \\
\text { and } 250 \mu \mathrm{M} \text { TRAP. } \\
\text { Mechanism: inhibits the phosphorylation of MAPK induced by collagen } 25 \mu \mathrm{g} / \mathrm{mL} \text {. } \\
\text { Inhibits in vivo the formation of the thrombus induced by collagen } 100 \mu \mathrm{g} / \mathrm{mL} \text {, under } \\
\text { controlled flow. Inhibits } \mathrm{FeCl}_{3} \text {-induced thrombus formation at } 50 \mu \mathrm{g} / \mathrm{mL} \text { [234]. }\end{array}$ \\
\hline \multirow{2}{*}{$\begin{array}{l}\text { Cyanidin-3-O- } \\
\text { glucoside }\end{array}$} & \multirow[t]{2}{*}{ Anthocyanin } & $\begin{array}{l}\text { Inhibits in vitro the secretion of alpha granules: PF4, } \beta \text {-TG, P-selectin, TGF- } \beta 1 \text {, } \\
\text { RANTES, ATP, and serotonin and CD63 induced with thrombin } 0.5 \mathrm{U} / \mathrm{mL} \text {. } \\
\text { Mechanism: inhibits the phosphorylation of the MAPK family induced by thrombin } \\
0.5 \mathrm{U} / \mathrm{mL} \text {. Inhibits PI3K/Akt activation, eNOS phosphorylation, and } 0.5 \mathrm{U} / \mathrm{mL} \\
\text { thrombin-induced cGMP production [233]. } \\
\text { Inhibits in vivo the secretion of alpha granules PF4, } \beta \text {-TG, P-selectin, TGF- } \beta 1 \text {, RANTES } \\
\text { induced with thrombin } 0.5 \mathrm{U} / \mathrm{mL} \text { at } 320 \mathrm{mg} / \text { day [233]. }\end{array}$ \\
\hline & & $\begin{array}{l}\text { Inhibits platelet aggregation induced with } 2.5 \mu \mathrm{g} / \mathrm{mL} \text { collagen, } 0.1 \mathrm{U} / \mathrm{mL} \text { thrombin, } \\
\text { and } 100 \mu \mathrm{M} \text { TRAP-6. } \\
\text { Mechanism: GPVI collagen receptor pathway. Inhibits collagen } 2.5 \mu \mathrm{g} / \mathrm{mL} \text { induced } \\
\text { phosphorylation of protein tyrosine at } 5-50 \mu \mathrm{M} \text { [235]. } \\
\text { Inhibits } 0.5-50 \mu \mathrm{M} \text { collagen-induced thrombus formation in vivo, under controlled flow. } \\
\text { Inhibits } \mathrm{FeCl}_{3} \text {-induced thrombus formation }(5-50 \mu \mathrm{M}) \text { [234]. }\end{array}$ \\
\hline
\end{tabular}


Table 1. Cont.

\begin{tabular}{|c|c|c|}
\hline Compound & Classification & Mechanisms \\
\hline \multirow{3}{*}{$\begin{array}{l}\text { Pelargonidine-3-O- } \\
\text { glucoside }\end{array}$} & \multirow{3}{*}{ Anthocyanin } & $\begin{array}{l}\text { Prolongs aPTT and PT. Inhibits thrombin and FXa activity and production in human } \\
\text { umbilical vein endothelial cells. Inhibits thrombin-catalyzed polymerization of fibrin } \\
\text { and platelet aggregation and anticoagulant effect elicited in mice }(10 \mu \mathrm{M})[236] \text {. }\end{array}$ \\
\hline & & $\begin{array}{l}\text { Inhibits in vitro the secretion of alpha granules: PF4, } \beta \text {-TG, P-selectin, TGF- } \beta 1 \text {, } \\
\text { RANTES, ATP, and serotonin and CD63 induced with thrombin } 0.5 \mathrm{U} / \mathrm{mL} \text {. } \\
\text { Inhibits the secretion of dense granules, ATP, and serotonin with thrombin } 0.5 \mathrm{U} / \mathrm{mL} \text {. } \\
\text { Mechanism: inhibition of the phosphorylation of the MAPK family induced by } \\
\text { thrombin } 0.5 \mathrm{U} / \mathrm{mL} \text {. Inhibits PI3K/Akt activation, eNOS phosphorylation, and } \\
0.5 \mathrm{U} / \mathrm{mL} \text { thrombin-induced cGMP production [233]. }\end{array}$ \\
\hline & & $\begin{array}{c}\text { Inhibits in vivo the secretion of alpha granules PF4, } \beta-T G, \text { P-selectin, TGF- } \beta 1, \text { RANTES } \\
\text { induced with thrombin } 0.5 \mathrm{U} / \mathrm{mL}(320 \mathrm{mg} / \text { day }) \text { [233]. }\end{array}$ \\
\hline
\end{tabular}

Abbreviations: AA: arachidonic acid, ADP: adenosine diphosphate, Akt: protein kinase B, aPTT: activated partial thromboplastin time, ATP: adenosine triphosphate, cAMP: cyclic adenosine monophosphate, CCL5: type 5 receptor chemokine, CD63: gene encoded by the symbol CD63, VSMC: vascular smooth muscle cells, COX-1: cyclooxygenase 1, DOX: doxorubicin, ecNOS: constitutive endothelial nitric oxide synthase, ERp5 reductase: endoplasmic reticulum protein 5, PLA: phospholipases A2, VWF: factor de von Willebrand, FXa: tissue factor, cGMP: cyclic guanosine monophosphate, GPIb: glycoprotein, IL-1ß: interleukin-1-beta, IP3: inositol triphosphate, LDH: lactate dehydrogenase, MAPK: mitogen-activated protein kinase, MCP-1: monocyte chemoattractant protein 1, MDA: malondialdehyde, NO: nitrogen oxide, PAF: platelet activating factor, PDE: phosphodiesterase, PDGF: platelet growth factor, PDI: protein disulfide isomerase, PECAM-1: molecule platelet-endothelium adhesion cells, PGI2: prostacyclin, PI(4,5)P2: phosphatidylinositol-4,5-bisphosphate, PKA: protein kinase A, PKC: protein kinase C, PLC: phospholipase, PMA: phorbol myristate acetate, PS: phosphatidylserine, PT: prothrombin time, RANTES: subfamily chemokine C, ROS: reactive oxygen species, sCD40L: differentiation groups or differentiation antigens, SMC: smooth muscular system, SOD: superoxide dismutase, TGF- $\beta 1$ : transforming growth factor beta-1, TNF- $\alpha$ : tumor necrosis factor alpha, TRAP: thrombin receptor activator for peptide 6, TxA2: thromboxane, VASP: vasodilator-activated phosphoprotein, VEGF: vascular endothelial growth factor, $\beta$-TG: $\beta$-thromboglobulin.

\section{In Silico Assays of Bioactive Compounds from Phaseolus vulgaris L.}

The development of structural elucidation by X-ray crystallography and bioinformatics has made it possible to identify and/or predict target-metabolite interactions. In this field, some studies have been carried out to determine the activity of metabolites present in Phaseolus vulgaris L. on different targets.

Petchiammal C. and Waheeta Hopper, 2011, performed molecular docking assays using 28 bioactive compounds from Phaseolus vulgaris extracted from Dr. Duke's database (https:/ / phytochem.nal.usda.gov/phytochem/plants/show/1470, accessed on 29 November 2021). These metabolites were evaluated as agonists of NOS, a therapeutic target that is found modulating the high pathological concentration of NO (antioxidant activity). The crystal structure utilized was the NOS heme domain (PDB: ID 3NLE) [237] (Figure 2a). Twenty-eight compounds from Phaseolus vulgaris were tested; among them, allantoic acid was found to have the best interaction with the residues present in the active site (Arg367) and the heme subunit of the NOS enzyme (Figure 2). To corroborate this, it was compared with the ligand present in the crystal. It was observed that the co-crystallized ligand also (allantoic acid) shows a better binding affinity toward the heme domain and the reported residues of the active site.

In silico analysis of allantoic acid from Phaseolus vulgaris L. suggests that this compound could have antioxidant activity by acting as an inhibitor of the NOS enzyme [238].

Peptides from Phaseolus vulgaris cv. Pinto has been evaluated as bioactive peptides in the $\mathrm{n}$ regulation of physiological functions: protease activation, lipase inhibition, and bile acid-binding activities. About nine peptides have been identified in Phaseolus vulgaris with protease activity and pancreatic lipase activity [239]. Ngoh et al., 2017, used the crystallographic structures of porcine gastric mucosa pepsin (PDB code: 5 PEP) [240] (Figure 2b), and porcine pancreatic lipase (PDB code: $1 \mathrm{ETH}$ ) (Figure 2c). In vitro and in silico analyses were able to demonstrate that five isolated peptides from Phaseolus vulgaris cv Pinto had a protease capacity, inhibiting the activity of pancreatic lipase and binding to bile acids. These results were able to demonstrate the efficacy of the peptides efficacy 
of Phaseolus vulgaris cv Pinto as therapeutic agents in the treatment and prevention of cardiovascular diseases (i.e., obesity, hyperlipidemia and hypercholesterolemia).

a
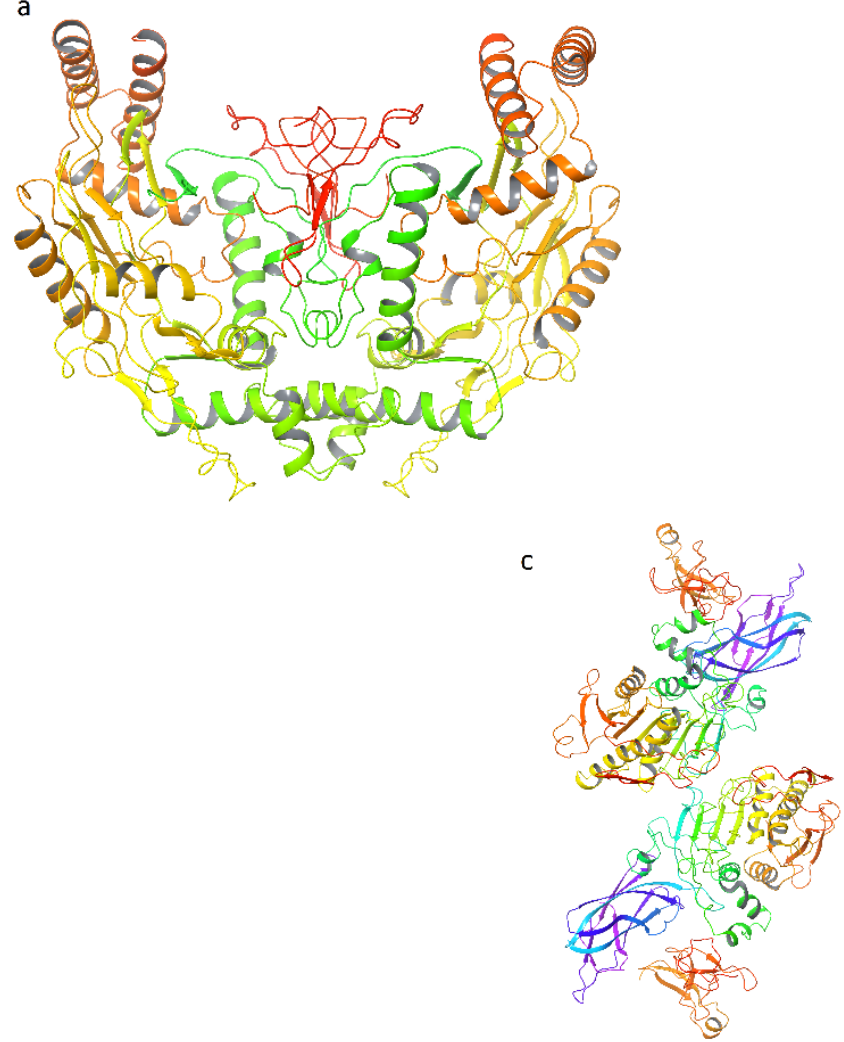

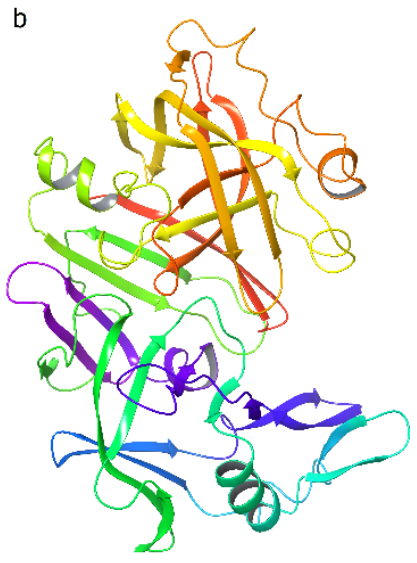

Figure 2. Targets studied about Phaseolus vulgaris. (a) NOS protein (PDB:ID 3NLE) [237]. (b) Porcine gastric mucosa (PDB code: 5PEP [240]. (c) Porcine pancreatic lipase (PDB code: 1 ETH) [241]. Source: adapted images according to PDB ID.

Important CVD-associated targets have been crystallized, among these are adenosine A2A receptor (PDB ID: 2YDV) [242] (Figure 3a), P2Y1 receptor (PDB ID:4XNV) [243] (Figure 3b), thromboxane receptor (TXA2) (PDB ID: 6IIU) [244] (Figure 3c), and protein kinase C (PDB ID: 2IOE and 1A25) [245,246].
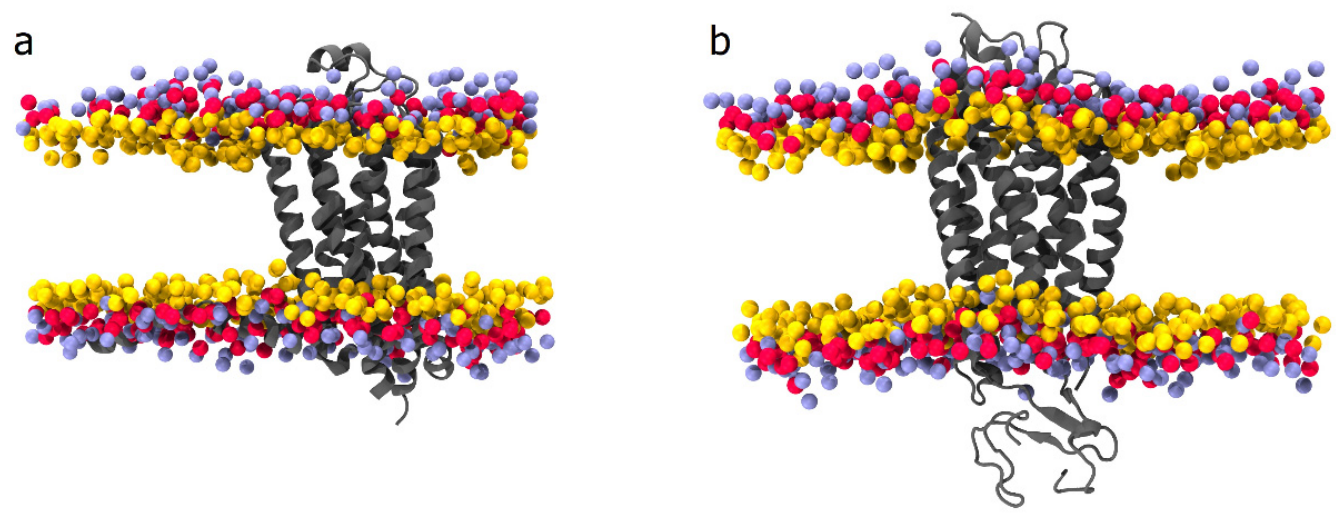

Figure 3. Cont. 


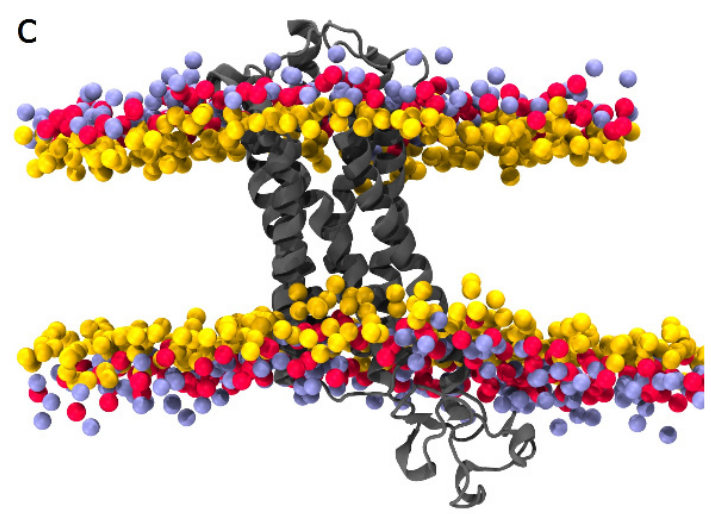

Figure 3. Therapeutic targets associated with CVD. (a) Adenosine A2A receptor (PDB ID: 2YDV) [242]. (b) P2Y1 receptor (PDB ID:4XNV) [243]. (c) Thromboxane receptor TxA2 (PDB ID: 6IIU) [244]. Source: all images were obtained from MemProtMD database according to the PDB ID [247].

The adenosine $\mathrm{A} 2 \mathrm{~A}$ receptor is a $\mathrm{G}$ protein-coupled receptor associated with numerous therapeutic applications. In platelets, activation of adenosine A2A receptors (Gscoupled receptor) is responsible for antiplatelet activity through increase intraplatelet cAMP levels [194,242,248].

The P2Y12 receptor (P2Y12R), one of eight members of the P2YR family expressed in humans, has been described as a relevant pharmacological target because its inhibition decreases platelet aggregation [249].

TXA2 receptor is expressed in platelets, inflammatory cells, the vascular wall, and atherosclerotic plaques [250]. Since the TXA2 receptor plays a vital role in cardiovascular homeostasis, it is considered a vital drug target for CVD [251].

The protein kinase $\mathrm{C}(\mathrm{PKC})$ family is a central regulator in platelet activation processes: granule secretion, integrin activation, aggregation, spreading, and procoagulant activity [252].

Future in silico research should focus on the analysis of CVD target crystallographic structures and the identification of metabolites present in Phaseolus vulgaris L. to obtain information relevant to the binding mode and the determination of a possible mechanism of action.

\section{Conclusions}

Diet is an important tool to maintain good cardiovascular health and thus reduce mortality and morbidity rates worldwide. This review has shown that the common bean is the food legume with the highest nutritional value, which has caused a greater demand for this product in low-income countries but also recently increased consumption in developed countries, which seek to guide their diet to a healthy style. It was shown that there is a positive correlation between the consumption of beans and the prevention of cardiovascular events (Figure 4). This legume has bioactive compounds (phenolic acids, flavonoids, fatty acids) that give it a unique value as a protector against the endothelium, inflammation, atherosclerosis, metabolic syndrome, among other pathologies of great impact on the population. The fundamental mechanisms on which this product influences have been related mainly to the inhibition of lipid peroxidation and lowering of cholesterol and blood glucose levels, among others. We recommend frequent consumption of beans because they can be used to improve nutritional wellbeing and prevent the prevalence of CVD. 


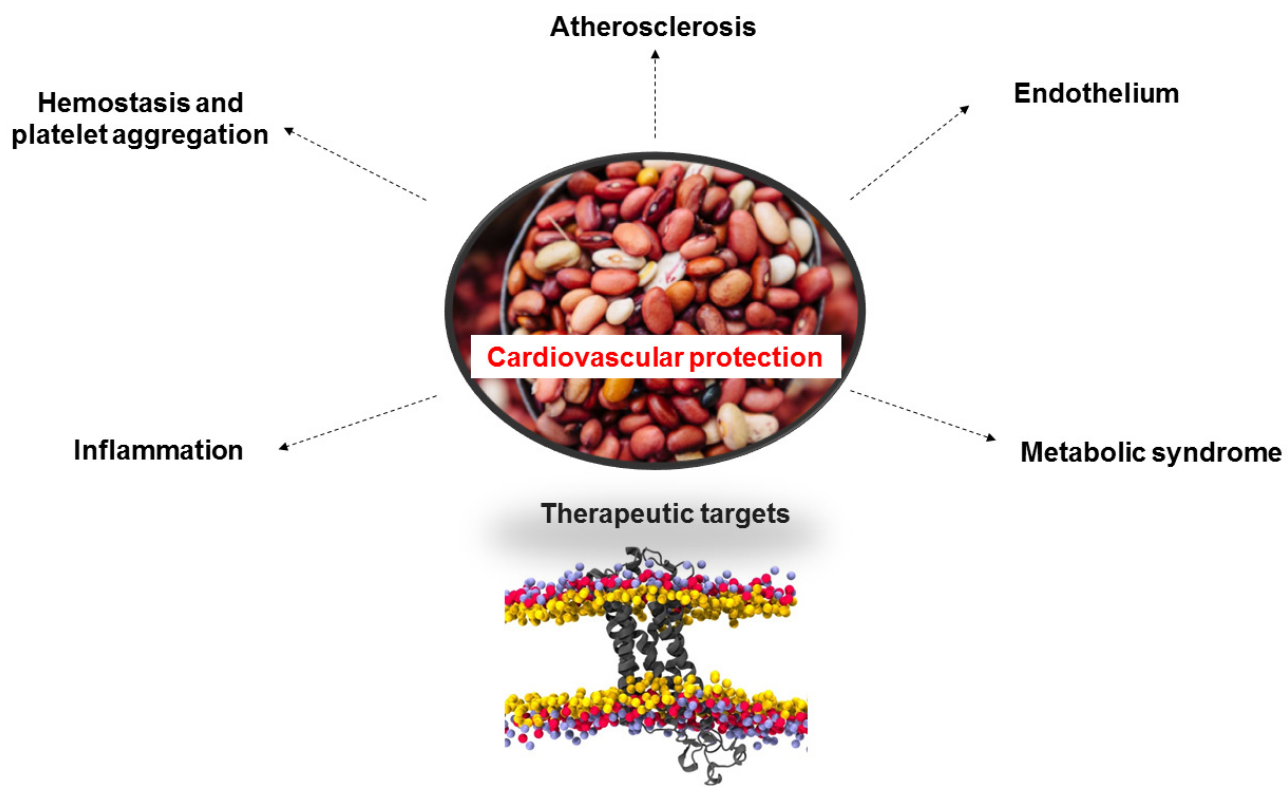

Figure 4. Cardioprotective Effects of Phaseolus vulgaris L. Source: created by the authors.

Author Contributions: L.R., D.M., H.M. and B.A.: writing-original draft preparation, conceptualization; E.F., B.C. and I.P.: writing-reviewing and editing. All authors have read and agreed to the published version of the manuscript.

Funding: This research was funded by Centro de Estudios en Alimentos Procesados-CEAP, ANID, Programa Regional R20F0001, Talca, Chile.

Institutional Review Board Statement: Not applicable.

Informed Consent Statement: Not applicable.

Data Availability Statement: Not applicable.

Conflicts of Interest: The authors have no conflict of interest to disclose.

\section{References}

1. Irfan, M.; Kwon, T.-H.; Lee, D.-H.; Hong, S.-B.; Oh, J.-W.; Kim, S.-D.; Rhee, M.H. Antiplatelet and antithrombotic effects of Epimedium koreanum Nakai. Evid.-Based Complement. Altern. Med. 2021, 2021, 7071987. [CrossRef]

2. Olas, B. Dietary supplements with antiplatelet activity: A solution for everyone? Adv. Nutr. 2018, 9, 51-57. [CrossRef]

3. Jackson, S.L.; Yang, E.C.; Zhang, Z. Income disparities and cardiovascular risk factors among adolescents. Pediatrics 2018, 142, e20181089. [CrossRef]

4. Mensah, G.A.; Roth, G.A.; Fuster, V. The global burden of cardiovascular diseases and risk factors: 2020 and beyond. J. Am. Coll. Cardiol. 2019, 74, 2529-2532. [CrossRef]

5. Rosengren, A.; Hawken, S.; Ônpuu, S.; Sliwa, K.; Zubaid, M.; Almahmeed, W.A.; Ngu Blackett, K.; Sitthi-Amorn, C.; Sato, H.; Yusuf, S.; et al. Association of psychosocial risk factors with risk of acute myocardial infarction in 11,119 cases and 13,648 controls from 52 countries (the INTERHEART study): Case-control study. Lancet 2004, 364, 953-962. [CrossRef]

6. Cuadrado-Godia, E.; Jamthikar, A.D.; Gupta, D.; Khanna, N.N.; Araki, T.; Maniruzzaman, M.; Saba, L.; Nicolaides, A.; Sharma, A.; Omerzu, T.; et al. Ranking of stroke and cardiovascular risk factors for an optimal risk calculator design: Logistic regression approach. Comput. Biol. Med. 2019, 108, 182-195. [CrossRef]

7. Kalantar-Zadeh, K.; Block, G.; Humphreys, M.H.; Kopple, J.D. Reverse epidemiology of cardiovascular risk factors in maintenance dialysis patients. Kidney Int. 2003, 63, 793-808. [CrossRef]

8. Niccoli, T.; Partridge, L. Ageing as a risk factor for disease. Curr. Biol. 2012, 22, R741-R752. [CrossRef]

9. Strait, J.B.; Lakatta, E.G. Aging-associated cardiovascular changes and their relationship to heart failure. Heart Fail. Clin. 2012, 8, 143-164. [CrossRef]

10. Zhang, S.; Liu, Y.; Wang, X.; Yang, L.; Li, H.; Wang, Y.; Liu, M.; Zhao, X.; Xie, Y.; Yang, Y.; et al. SARS-CoV-2 binds platelet ACE2 to enhance thrombosis in COVID-19. J. Hematol. Oncol. 2020, 13, 120. [CrossRef]

11. Huang, J.; Li, X.; Shi, X.; Zhu, M.; Wang, J.; Huang, S.; Huang, X.; Wang, H.; Li, L.; Deng, H.; et al. Platelet integrin $\alpha I I b \beta 3:$ Signal transduction, regulation, and its therapeutic targeting. J. Hematol. Oncol. 2019, 12, 26. [CrossRef] 
12. Meshkini, A.; Tahmasbi, M. Antiplatelet aggregation activity of walnut hull extract via suppression of reactive oxygen species generation and caspase activation. J. Acupunct. Meridian Stud. 2017, 10, 193-203. [CrossRef]

13. Tsoupras, A.; Lordan, R.; Zabetakis, I. Thrombosis and COVID-19: The potential role of nutrition. Front. Nutr. 2020, 7, 177. [CrossRef]

14. Tsoupras, A.; Lordan, R.; Zabetakis, I. Inflammation, not cholesterol, is a cause of chronic disease. Nutrients 2018, 10, 604. [CrossRef]

15. Yu, E.; Malik, V.S.; Hu, F.B. Cardiovascular disease prevention by diet modification: JACC health promotion series. J. Am. Coll. Cardiol. 2018, 72, 914-926. [CrossRef]

16. Calder, P.C.; Carr, A.C.; Gombart, A.F.; Eggersdorfer, M. optimal nutritional status for a well-functioning immune system is an important factor to protect against viral infections. Nutrients 2020, 12, 1181. [CrossRef]

17. Bartimoccia, S.; Nocella, C.; Pastori, D.; Pignatelli, P.; Carnevale, R. Platelet oxidative stress and antioxidant nutrients. J. Vasc. Med. Surg. 2014, 2, 1000164.

18. Violi, F.; Pignatelli, P. Platelet oxidative stress and thrombosis. Thromb. Res. 2012, 129, 378-381. [CrossRef]

19. Câmara, C.R.S.; Urrea, C.A.; Schlegel, V. Pinto beans (Phaseolus vulgaris L.) as a functional food: Implications on human health. Agriculture 2013, 3, 90-111. [CrossRef]

20. Bellucci, E.; Bitocchi, E.; Rau, D.; Rodriguez, M.; Biagetti, E.; Giardini, A.; Attene, G.; Nanni, L.; Papa, R. Genomics of origin, domestication and evolution of Phaseolus vulgaris. Genom. Plant Genet. Resour. 2014, 483-507. [CrossRef]

21. Yanez, E.; Zacarias, I.; Aguayo, M.; Vasquez, M.; Guzman, E. Nutritive value evaluated on rats of new cultivars of common beans (Phaseolus vulgaris) released in Chile. Plant Foods Hum. Nutr. 1995, 47, 301-307. [CrossRef]

22. de Almeida Costa, G.E.; da Silva Queiroz-Monici, K.; Reis, S.M.P.M.; de Oliveira, A.C. Chemical composition, dietary fibre and resistant starch contents of raw and cooked pea, common bean, chickpea and lentil legumes. Food Chem. 2006, 94, 327-330. [CrossRef]

23. Lin, L.-Z.; Harnly, J.M.; Pastor-Corrales, M.S.; Luthria, D.L. The polyphenolic profiles of common bean (Phaseolus vulgaris L.). Food Chem. 2008, 107, 399-410. [CrossRef]

24. Tharanathan, R.N.; Mahadevamma, S. Grain legumes-A boon to human nutrition. Trends Food Sci. Technol. 2003, 14, 507-518. [CrossRef]

25. Shimelis, E.A.; Rakshit, S.K. Proximate composition and physico-chemical properties of improved dry bean (Phaseolus vulgaris L.) varieties grown in Ethiopia. LWT-Food Sci. Technol. 2005, 38, 331-338. [CrossRef]

26. Hayat, I.; Ahmad, A.; Masud, T.; Ahmed, A.; Bashir, S. Nutritional and health perspectives of beans (Phaseolus vulgaris L.): An overview. Crit. Rev. Food Sci. Nutr. 2014, 54, 580-592. [CrossRef]

27. Siddiq, M.; Ravi, R.; Harte, J.B.; Dolan, K.D. Physical and functional characteristics of selected dry bean (Phaseolus vulgaris L.) flours. LWT-Food Sci. Technol. 2010, 43, 232-237. [CrossRef]

28. Landon, A.J. The "how" of the three sisters: The origins of agriculture in Mesoamerica and the human niche. Neb. Anthropol. 2008, 23, 110-124

29. Celmeli, T.; Sari, H.; Canci, H.; Sari, D.; Adak, A.; Eker, T.; Toker, C. The nutritional content of common bean (Phaseolus vulgaris L.) landraces in comparison to modern varieties. Agronomy 2018, 8, 166. [CrossRef]

30. Gepts, P. Phaseolus vulgaris (beans). Encycl. Genet. 2001, 1444-1445.

31. Singh, S.P. Broadening the genetic base of common bean cultivars: A review. Crop Sci. 2001, 41, 1659-1675. [CrossRef]

32. Bitocchi, E.; Rau, D.; Bellucci, E.; Rodriguez, M.; Murgia, M.L.; Gioia, T.; Santo, D.; Nanni, L.; Attene, G.; Papa, R. Beans (Phaseolus ssp.) as a model for understanding crop evolution. Front. Plant Sci. 2017, 8, 722. [CrossRef]

33. Acosta-Gallegos, J.A.; Kelly, J.D.; Gepts, P. Prebreeding in common bean and use of genetic diversity from wild germplasm. Crop Sci. 2007, 47, S-44-S-59. [CrossRef]

34. Marquezi, M.; Gervin, V.M.; Watanabe, L.B.; Moresco, R.; Amante, E.R. Chemical and functional properties of different common Brazilian bean (Phaseolus vulgaris L.) cultivars. Braz. J. Food Technol. 2017, 20, e2016006. [CrossRef]

35. Leterme, P.; Muũoz, L.C. Factors influencing pulse consumption in Latin America. Br. J. Nutr. 2002, 88, 251-254. [CrossRef]

36. Luthria, D.L.; Pastor-Corrales, M.A. Phenolic acids content of fifteen dry edible bean (Phaseolus vulgaris L.) varieties. J. Food Compos. Anal. 2006, 19, 205-211. [CrossRef]

37. Akibode, C.S.; Maredia, M.K. Global and Regional Trends in Production, Trade and Consumption of Food Legume Crops. 2012. Available online: https:/ / ageconsearch.umn.edu/record/136293 (accessed on 15 October 2012).

38. Paredes, M.; Becerra, V.; Tay, J. Inorganic nutritional composition of common bean (Phaseolus vulgaris L.) genotypes race Chile. Chil. J. Agric. Res. 2009, 69, 486-495. [CrossRef]

39. Shellie-Dessert, K.C.; Bliss, F.A. Genetic improvement of food quality factors. In Common Beans: Research for Crop Improvement; Schoonhoven, A., vanVoysest, O., Eds.; CAB International: Wallingford, UK, 1991; pp. 649-677.

40. Choung, M.-G.; Choi, B.-R.; An, Y.-N.; Chu, Y.-H.; Cho, Y.-S. Anthocyanin profile of Korean cultivated kidney bean (Phaseolus vulgaris L.). J. Agric. Food Chem. 2003, 51, 7040-7043. [CrossRef]

41. Aparicio-Fernández, X.; García-Gasca, T.; Yousef, G.G.; Lila, M.A.; González de Mejia, E.; Loarca-Pina, G. Chemopreventive activity of polyphenolics from black Jamapa bean (Phaseolus vulgaris L.) on HeLa and HaCaT cells. J. Agric. Food Chem. 2006 54, 2116-2122. [CrossRef]

42. Hosfield, G.L.; Varner, G.V.; Uebersax, M.A.; Kelly, J.D. Registration of 'Merlot' small red bean. Crop Sci. 2004, 44, 351-353. [CrossRef]

43. Amir, Y.; Haenni, A.L.; Youyou, A. Differences in the biochemical composition of dry legumes cultivated in north Algeria. Electron J. Environ. Agric Food Chem. 2006, 5, 1411-1418.

44. Baginsky, C.; Ramos, L. Situación de las legumbres en Chile: Una mirada agronómica. Rev. Chil. Nutr. 2018, 45, 21-31. [CrossRef] 
45. Broughton, W.J.; Hernandez, G.; Blair, M.; Beebe, S.; Gepts, P.; Vanderleyden, J. Beans (Phaseolus spp.)—Model food legumes. Plant Soil 2003, 252, 55-128. [CrossRef]

46. Baginsky, C.; Brito, B.; Scherson, R.; Pertuzé, R.; Seguel, O.; Cañete, A.; Araneda, C.; Johnson, W. Genetic diversity of Rhizobium from nodulating beans grown in a variety of Mediterranean climate soils of Chile. Arch. Microbiol. 2015, 197, 419-429. [CrossRef]

47. Olanipekun, O.T.; Omenna, E.C.; Olapade, O.A.; Suleiman, P.; Omodara, O.G. Effect of boiling and roasting on the nutrient composition of kidney beans seed flour. Sky J. Food Sci. 2015, 4, 24-29.

48. Singh, S.P.; Gepts, P.; Debouck, D.G. Races of common bean (Phaseolus vulgaris, Fabaceae). Econ. Bot. 1991, 45, 379-396. [CrossRef]

49. Bascur, G.B.; Tay, J.U. Collection, characterization and use of genetic variation in Chilean bean germplasm (Phaseolus vulgaris L.) 1. Agric. Técnica 2005, 65, 135-146.

50. Trucchi, E.; Benazzo, A.; Lari, M.; Iob, A.; Vai, S.; Nanni, L.; Bellucci, E.; Bitocchi, E.; Raffini, F.; Xu, C.; et al. Ancient genomes reveal early Andean farmers selected common beans while preserving diversity. Nat. Plants 2021, 7, 123-128. [CrossRef]

51. Yang, Q.Q.; Gan, R.Y.; Ge, Y.Y.; Zhang, D.; Corke, H. Polyphenols in common beans (Phaseolus vulgaris L.): Chemistry, analysis, and factors affecting composition. Compr. Rev. Food Sci. Food Saf. 2018, 17, 1518-1539. [CrossRef]

52. Chen, P.X.; Tang, Y.; Marcone, M.F.; Pauls, P.K.; Zhang, B.; Liu, R.; Tsao, R. Characterization of free, conjugated and bound phenolics and lipophilic antioxidants in regular-and non-darkening cranberry beans (Phaseolus vulgaris L.). Food Chem. 2015, 185, 298-308. [CrossRef]

53. Teixeira-Guedes, C.I.; Oppolzer, D.; Barros, A.I.; Pereira-Wilson, C. Impact of cooking method on phenolic composition and antioxidant potential of four varieties of Phaseolus vulgaris L. and Glycine max L. LWT 2019, 103, 238-246. [CrossRef]

54. Los, F.G.B.; Zielinski, A.A.F.; Wojeicchowski, J.P.; Nogueira, A.; Demiate, I.M. Beans (Phaseolus vulgaris L.): Whole seeds with complex chemical composition. Curr. Opin. Food Sci. 2018, 19, 63-71. [CrossRef]

55. Madrera, R.R.; Valles, B.S. Development and validation of ultrasound assisted extraction (UAE) and HPLC-DAD method for determination of polyphenols in dry beans (Phaseolus vulgaris). J. Food Compos. Anal. 2020, 85, 103334. [CrossRef]

56. Yang, Q.-Q.; Gan, R.-Y.; Ge, Y.-Y.; Zhang, D.; Corke, H. Ultrasonic treatment increases extraction rate of common bean (Phaseolus vulgaris L.) antioxidants. Antioxidants 2019, 8, 83. [CrossRef]

57. Pitura, K.; Arntfield, S.D. Characteristics of flavonol glycosides in bean (Phaseolus vulgaris L.) seed coats. Food Chem. 2019, 272, 26-32. [CrossRef]

58. Flores-Sosa, Á.R.; Aquino-Bolaños, E.N.; Cardador-Martínez, A.; Chávez-Servia, J.L.; Vera-Guzmán, A.M.; Carrillo-Rodríguez, J.C.; Jiménez, J.E.A. Variation in protein and amino acids content among landraces of common bean (Phaseolus vulgaris L.). Emir. J. Food Agric. 2020, 32, 750-760. [CrossRef]

59. Yoshida, H.; Yoshida, N.; Tomiyama, Y.; Mizushina, Y. Fatty acid characteristics of triacylglycerols and phospholipids in adzuki beans (Vigna angularis). Food Sci. Technol. Res. 2010, 16, 209-214. [CrossRef]

60. Kotha, R.R.; Finley, J.W.; Luthria, D.L. Determination of soluble mono, di, and oligosaccharide content in 23 dry beans (Phaseolus vulgaris L.). J. Agric. Food Chem. 2020, 68, 6412-6419. [CrossRef]

61. Díaz-Batalla, L.; Widholm, J.M.; Fahey, G.C.; Castaño-Tostado, E.; Paredes-López, O. Chemical components with health implications in wild and cultivated Mexican common bean seeds (Phaseolus vulgaris L.). J. Agric. Food Chem. 2006, 54, 2045-2052. [CrossRef]

62. Pereira, H.S.; Alvares, R.C.; Melo, L.C.; Da Costa, A.F.; De Carvalho, H.W.L. Culinary and nutritional quality of common bean lines with Carioca grain type and interaction with environments. Rev. Ceres 2017, 64, 159-166. [CrossRef]

63. Nouri, F.; Sarrafzadegan, N.; Mohammadifard, N.; Sadeghi, M.; Mansourian, M. Intake of legumes and the risk of cardiovascular disease: Frailty modeling of a prospective cohort study in the Iranian middle-aged and older population. Eur. J. Clin. Nutr. 2016, 70, 217-221. [CrossRef]

64. Batista, K.A.; Prudêncio, S.H.; Fernandes, K.F. Wheat bread enrichment with hard-to-cook bean extruded flours: Nutritional and acceptance evaluation. J. Food Sci. 2011, 76, S108-S113. [CrossRef]

65. Seena, S.; Sridhar, K.R.; Bhagya, B. Biochemical and biological evaluation of an unconventional legume, Canavalia maritima of coastal sand dunes of India. Trop. Subtrop. Agroecosyst. 2005, 5, 1-14.

66. Słupski, J. Effect of cooking and sterilisation on the composition of amino acids in immature seeds of flageolet bean (Phaseolus vulgaris L.) cultivars. Food Chem. 2010, 121, 1171-1176. [CrossRef]

67. Derbyshire, E.; Wright, D.J.; Boulter, D. Legumin and vicilin, storage proteins of legume seeds. Phytochemistry 1976, 15, 3-24. [CrossRef]

68. Guzmán-Maldonado, S.H.; Acosta-Gallegos, J.; Paredes-López, O. Protein and mineral content of a novel collection of wild and weedy common bean (Phaseolus vulgaris L.). J. Sci. Food Agric. 2000, 80, 1874-1881. [CrossRef]

69. Baptista, A.; Pinho, O.; Pinto, E.; Casal, S.; Mota, C.; Ferreira, I.M. Characterization of protein and fat composition of seeds from common beans (Phaseolus vulgaris L.), cowpea (Vigna unguiculata L. Walp) and bambara groundnuts (Vigna subterranea L. Verdc) from Mozambique. J. Food Meas. Charact. 2017, 11, 442-450. [CrossRef]

70. Carbas, B.; Machado, N.; Oppolzer, D.; Ferreira, L.; Queiroz, M.; Brites, C.; Rosa, E.A.; Barros, A.I. Nutrients, antinutrients, phenolic composition, and antioxidant activity of common bean cultivars and their potential for food applications. Antioxidants 2020, 9, 186. [CrossRef]

71. Boye, J.; Wijesinha-Bettoni, R.; Burlingame, B. Protein quality evaluation twenty years after the introduction of the protein digestibility corrected amino acid score method. Br. J. Nutr. 2012, 108, S183-S211. [CrossRef]

72. Grimble, R.F. The effects of sulfur amino acid intake on immune function in humans. J. Nutr. 2006, 136, 1660S-1665S. [CrossRef] 
73. Vargas-Torres, A.; Osorio-Díaz, P.; Islas-Hernández, J.J.; Tovar, J.; Paredes-López, O.; Bello-Pérez, L.A. Starch digestibility of five cooked black bean (Phaseolus vulgaris L.) varieties. J. Food Compos. Anal. 2004, 17, 605-612. [CrossRef]

74. Ovando-Martínez, M.; Bello-Pérez, L.A.; Whitney, K.; Osorio-Díaz, P.; Simsek, S. Starch characteristics of bean (Phaseolus vulgaris L.) grown in different localities. Carbohydr. Polym. 2011, 85, 54-64. [CrossRef]

75. Tharanathan, R.N. Food-derived carbohydrates-Structural complexity and functional diversity. Crit. Rev. Biotechnol. 2002, 22, 65-84. [CrossRef]

76. Zhou, Y.; Hoover, R.; Liu, Q. Relationship between $\alpha$-amylase degradation and the structure and physicochemical properties of legume starches. Carbohydr. Polym. 2004, 57, 299-317. [CrossRef]

77. Reynoso-Camacho, R.; Ramos-Gomez, M.; Loarca-Pina, G. Bioactive components in common beans (Phaseolus vulgaris L.). Adv. Agric. Food Biotechnol. 2006, 10, 217-236.

78. Yoshida, H.; Tomiyama, Y.; Mizushina, Y. Characterization in the fatty acid distributions of triacylglycerols and phospholipids in kidney beans (Phaseolus vulgaris L.). J. Food Lipids 2005, 12, 169-180. [CrossRef]

79. Ryan, E.; Galvin, K.; O'Connor, T.P.; Maguire, A.; O'Brien, N.M. Phytosterol, squalene, tocopherol content and fatty acid profile of selected seeds, grains, and legumes. Mater. Veg. 2007, 62, 85-91. [CrossRef]

80. Grela, E.R.; Günter, K.D. Fatty acid composition and tocopherol content of some legume seeds. Anim. Feed Sci. Technol. 1995, 52, 325-331. [CrossRef]

81. Beninger, C.W.; Hosfield, G.L. Antioxidant activity of extracts, condensed tannin fractions, and pure flavonoids from Phaseolus vulgaris L. seed coat color genotypes. J. Agric. Food Chem. 2003, 51, 7879-7883. [CrossRef]

82. Vucenik, I.; Shamsuddin, A.M. Protection against cancer by dietary IP6 and inositol. Nutr. Cancer 2006, 55, 109-125. [CrossRef]

83. Bennink, M.R. Consumption of black beans and navy beans (Phaseolus vulgaris) reduced azoxymethane-induced colon cancer in rats. Nutr. Cancer 2002, 44, 60-65. [CrossRef]

84. Xu, B.; Chang, S.K.C. Comparative study on antiproliferation properties and cellular antioxidant activities of commonly consumed food legumes against nine human cancer cell lines. Food Chem. 2012, 134, 1287-1296. [CrossRef]

85. Sangronis, E.; Machado, C.J. Influence of germination on the nutritional quality of PhaseolusLWT vulgaris and Cajanus cajan. LWT-Food Sci. Technol. 2007, 40, 116-120. [CrossRef]

86. Mitchell, D.C.; Lawrence, F.R.; Hartman, T.J.; Curran, J.M. Consumption of dry beans, peas, and lentils could improve diet quality in the US population. J. Am. Diet. Assoc. 2009, 109, 909-913. [CrossRef]

87. Rosa, C.O.; Costa, N.M.; Leal, P.F.; Oliveira, T.T. The cholesterol-lowering effect of black beans (Phaseolus vulgaris, L.) without hulls in hypercholesterolemic rats. Arch. Latinoam. Nutr. 1998, 48, 299-305.

88. Anderson, J.W.; Smith, B.M.; Washnock, C.S. Cardiovascular and renal benefits of dry bean and soybean intake. Am. J. Clin. Nutr. 1999, 70, 464S-474S. [CrossRef]

89. Heimler, D.; Vignolini, P.; Dini, M.G.; Romani, A. Rapid tests to assess the antioxidant activity of Phaseolus vulgaris L. dry beans. J. Agric. Food Chem. 2005, 53, 3053-3056. [CrossRef]

90. Olas, B. The multifunctionality of berries toward blood platelets and the role of berry phenolics in cardiovascular disorders. Platelets 2017, 28, 540-549. [CrossRef]

91. Fuentes, E.; Palomo, I. Antiplatelet effects of natural bioactive compounds by multiple targets: Food and drug interactions J. Funct. Foods 2014, 6, 73-81. [CrossRef]

92. Rodríguez-Azúa, R.; Quinteros, E.F.; Olate-Briones, A.; Moore-Carrasco, R. Phaseolus vulgaris exerts an inhibitory effect on platelet aggregation through AKT dependent way. Prev. Nutr. Food Sci. 2018, 23, 102. [CrossRef]

93. Vaiyapuri, S.; Roweth, H.; Ali, M.S.; Unsworth, A.J.; Stainer, A.R.; Flora, G.D.; Crescente, M.; Jones, C.I.; Moraes, L.A.; Gibbins, J.M Pharmacological actions of nobiletin in the modulation of platelet function. Br. J. Pharmacol. 2015, 172, 4133-4145. [CrossRef]

94. Ganguly, P.; Gould, N.L.; Sidhu, P. Interaction of lectins with human platelets: Effects of platelet stimulation by thrombin and ristocetin. Biochim. Biophys. Acta (BBA)-Gen. Subj. 1979, 586, 574-583. [CrossRef]

95. Signorello, M.G.; Ravera, S.; Leoncini, G. Lectin-induced oxidative stress in human platelets. Redox Biol. 2020, 32, 101456. [CrossRef]

96. Kinlough-Rathbone, R.L.; Mustard, J.F.; Packham, M.A.; Perry, D.W.; Reimers, H.-J.; Cazenave, J.-P. Properties of washed human platelets. Thromb. Haemost. 1977, 37, 291-308. [CrossRef]

97. Cazenave, J.P.; Guccione, M.A.; Packham, M.A.; Mustard, J.F. Effects of cephalothin and penicillin G on platelet function in vitro. Br. J. Haematol. 1977, 35, 135-152. [CrossRef]

98. Signorello, M.G.; Leoncini, G. The $\mathrm{Ca}^{2+}$ /calmodulin kinase/AMP-activated protein kinase pathway regulates the lectin Phaseolus vulgaris agglutinin induced NO production in human platelets. Integr. Mol. Med. 2019, 6, 1-9. [CrossRef]

99. Wang, G.-R.; Zhu, Y.; Halushka, P.V.; Lincoln, T.M.; Mendelsohn, M.E. Mechanism of platelet inhibition by nitric oxide: In vivo phosphorylation of thromboxane receptor by cyclic GMP-dependent protein kinase. Proc. Natl. Acad. Sci. USA 1998, 95, 4888-4893. [CrossRef]

100. Schemmer, P.; Zhong, Z.; Galli, U.; Wheeler, M.D.; Xiangli, L.; Bradford, B.U.; Conzelmann, L.O.; Forman, D.; Boyer, J.; Thurman, R.G. Glycine reduces platelet aggregation. Amino Acids 2013, 44, 925-931. [CrossRef]

101. Wolf, A.; Zalpour, C.; Theilmeier, G.; Wang, B.-Y.; Ma, A.; Anderson, B.; Tsao, P.S.; Cooke, J.P. Dietary L-arginine supplementation normalizes platelet aggregation in hypercholesterolemic humans. J. Am. Coll. Cardiol. 1997, 29, 479-485. [CrossRef]

102. Thompson, K.; Hosking, H.; Pederick, W.; Singh, I.; Santhakumar, A.B. The effect of anthocyanin supplementation in modulating platelet function in sedentary population: A randomised, double-blind, placebo-controlled, cross-over trial. Br. J. Nutr. 2017, 118, 368-374. [CrossRef] 
103. Adili, R.; Hawley, M.; Holinstat, M. Regulation of platelet function and thrombosis by omega-3 and omega- 6 polyunsaturated fatty acids. Prostaglandins Other Lipid Mediat. 2018, 139, 10-18. [CrossRef]

104. Dratewka-Kos, E.; Tinker, D.O.; Kindl, B. Unsaturated fatty acids inhibit ADP-arachidonate-induced platelet aggregation without affecting thromboxane synthesis. Biochem. Cell Biol. 1986, 64, 906-913. [CrossRef]

105. McEwen, B.J.; Morel-Kopp, M.-C.; Chen, W.; Tofler, G.H.; Ward, C.M. Effects of omega-3 polyunsaturated fatty acids on platelet function in healthy subjects and subjects with cardiovascular disease. Semin. Thromb. Hemost. 2013, 39, 25-32. [CrossRef]

106. Hodgson, J.M.; Wahlqvist, M.L.; Boxall, J.A.; Balazs, N.D. Can linoleic acid contribute to coronary artery disease? Am. J. Clin. Nutr. 1993, 58, 228-234. [CrossRef]

107. Dinicolantonio, J.; Okeefe, J. Importance of maintaining a low omega-6/omega-3 ratio for reducing platelet aggregation, coagulation and thrombosis. Open Heart 2019, 6, e001011. [CrossRef]

108. Miyake, K.; Tanaka, T.; McNeil, P.L. Lectin-based food poisoning: A new mechanism of protein toxicity. PLoS ONE 2007, 2, e687. [CrossRef]

109. Luna-Vital, D.A.; De Mejía, E.G.; Mendoza, S.; Loarca-Piña, G. Peptides present in the non-digestible fraction of common beans (Phaseolus vulgaris L.) inhibit the angiotensin-I converting enzyme by interacting with its catalytic cavity independent of their antioxidant capacity. Food Funct. 2015, 6, 1470-1479. [CrossRef]

110. Gomes, M.J.; Lima, S.L.; Alves, N.E.G.; Assis, A.; Moreira, M.E.; Toledo, R.C.; Rosa, C.O.; Teixeira, O.R.; Bassinello, P.Z.; De Mejía, E.G.; et al. Common bean protein hydrolysate modulates lipid metabolism and prevents endothelial dysfunction in BALB/c mice fed an atherogenic diet. Nutr. Metab. Cardiovasc. Dis. 2020, 30, 141-150. [CrossRef]

111. Davis, H.R.; Glagov, S. Lectin binding to distinguish cell types in fixed atherosclerotic arteries. Atherosclerosis 1986, 61, 193-203. [CrossRef]

112. Zehr, K.R.; Walker, M.K. Omega-3 polyunsaturated fatty acids improve endothelial function in humans at risk for atherosclerosis: A review. Prostaglandins Other Lipid Mediat. 2018, 134, 131-140. [CrossRef]

113. Kakoki, M.; Kim, H.-S.; Edgell, C.-J.S.; Maeda, N.; Smithies, O.; Mattson, D.L. Amino acids as modulators of endothelium-derived nitric oxide. Am. J. Physiol.-Ren. Physiol. 2006, 291, F297-F304. [CrossRef]

114. Gamboa-Gomez, C.I.; Rocha-Guzman, N.E.; Gallegos-Infante, J.A.; Moreno-Jimenez, M.R.; Vazquez-Cabral, B.D.; Gonzalez-Laredo, R.F. Plants with potential use on obesity and its complications. EXCLI J. 2015, 14, 809-831.

115. Lefkowitz, D.L.; Lefkowitz, S.S. Macrophage-neutrophil interaction: A paradigm for chronic inflammation revisited. Immunol. Cell Biol. 2001, 79, 502-506. [CrossRef]

116. Williams, C.S.; Mann, M.; DuBois, R.N. The role of cyclooxygenases in inflammation, cancer, and development. Oncogene 1999, 18, 7908-7916. [CrossRef]

117. Alves, N.E.G.; de Mejía, E.G.; Vasconcelos, C.M.; Bassinello, P.Z.; Martino, H.S.D. Postharvest storage of Carioca bean (Phaseolus vulgaris L.) did not impair inhibition of inflammation in lipopolysaccharide-induced human THP-1 macrophage-like cells. J. Funct. Foods 2016, 23, 154-166. [CrossRef]

118. Monsalve, F.A.; Pyarasani, R.D.; Delgado-Lopez, F.; Moore-Carrasco, R. Peroxisome proliferator-activated receptor targets for the treatment of metabolic diseases. Mediat. Inflamm. 2013, 2013, 549627. [CrossRef]

119. de Lima, S.L.S.; Gomes, M.J.C.; da Silva, B.P.; Alves, N.E.G.; Toledo, R.C.L.; Theodoro, J.M.V.; Moreira, M.E.C.; Bento, J.A.C.; Bassinello, P.Z.; da Matta, S.L.P.; et al. Whole flour and protein hydrolysate from common beans reduce the inflammation in BALB/c mice fed with high fat high cholesterol diet. Food Res. Int. 2019, 122, 330-339. [CrossRef]

120. Oseguera-Toledo, M.E.; De Mejia, E.G.; Dia, V.P.; Amaya-Llano, S.L. Common bean (Phaseolus vulgaris L.) hydrolysates inhibit inflammation in LPS-induced macrophages through suppression of NF-kB pathways. Food Chem. 2011, 127, 1175-1185. [CrossRef]

121. Grancieri, M.; Martino, H.S.D.; de Mejia, E.G. Protein Digests and pure peptides from chia seed prevented adipogenesis and inflammation by inhibiting PPAR $\gamma$ and NF-кB pathways in 3T3L-1 adipocytes. Nutrients 2021, 13, 176. [CrossRef]

122. Hwang, S.-J.; Song, Y.-S.; Lee, H.-J. Phaseolin attenuates lipopolysaccharide-induced inflammation in RAW 264.7 cells and zebrafish. Biomedicines 2021, 9, 420. [CrossRef]

123. Kim, S.; Hong, J.; Jeon, R.; Kim, H.-S. Adzuki bean ameliorates hepatic lipogenesis and proinflammatory mediator expression in mice fed a high-cholesterol and high-fat diet to induce nonalcoholic fatty liver disease. Nutr. Res. 2016, 36, 90-100. [CrossRef]

124. Rodríguez, E.; Ribot, J.; Rodríguez, A.M.; Palou, A. PPAR- $\gamma 2$ expression in response to cafeteria diet: Gender- and depot-specific effects. Obes. Res. 2004, 12, 1455-1463. [CrossRef]

125. Oomah, B.D.; Corbé, A.; Balasubramanian, P. Antioxidant and anti-inflammatory activities of bean (Phaseolus vulgaris L.) hulls. J. Agric. Food Chem. 2010, 58, 8225-8230. [CrossRef]

126. Borresen, E.C.; Brown, D.G.; Harbison, G.; Taylor, L.; Fairbanks, A.; O’Malia, J.; Bazan, M.; Rao, S.; Bailey, S.M.; Wdowik, M.; et al. A randomized controlled trial to increase navy bean or rice bran consumption in colorectal cancer survivors. Nutr. Cancer 2016, 68, 1269-1280. [CrossRef]

127. Kunnumakkara, A.B.; Sailo, B.L.; Banik, K.; Harsha, C.; Prasad, S.; Gupta, S.C.; Bharti, A.C.; Aggarwal, B.B. Chronic diseases, inflammation, and spices: How are they linked? J. Transl. Med. 2018, 16, 14. [CrossRef]

128. Shi, Y.; Zou, Y.; Shen, Z.; Xiong, Y.; Zhang, W.; Liu, C.; Chen, S. Trace Elements, PPARs, and Metabolic Syndrome. Int. J. Mol. Sci. 2020, 21, 2612. [CrossRef]

129. Katsimardou, A.; Imprialos, K.; Stavropoulos, K.; Sachinidis, A.; Doumas, M.; Athyros, V. Hypertension in metabolic syndrome: Novel Insights. Curr. Hypertens. Rev. 2020, 16, 12-18. [CrossRef]

130. Castro-Barquero, S.; Ruiz-Leon, A.M.; Sierra-Perez, M.; Estruch, R.; Casas, R. Dietary strategies for metabolic syndrome: A comprehensive review. Nutrients 2020, 12, 2983. [CrossRef] 
131. Perez-Martinez, P.; Mikhailidis, D.P.; Athyros, V.G.; Bullo, M.; Couture, P.; Covas, M.I.; de Koning, L.; Delgado-Lista, J.; Díaz-López, A.; Drevon, C.A.; et al. Lifestyle recommendations for the prevention and management of metabolic syndrome: An international panel recommendation. Nutr. Rev. 2017, 75, 307-326. [CrossRef]

132. Jakubczyk, A.; Karas, M.; Zlotek, U.; Szymanowska, U. Identification of potential inhibitory peptides of enzymes involved in the metabolic syndrome obtained by simulated gastrointestinal digestion of fermented bean (Phaseolus vulgaris L.) seeds. Food Res. Int. 2017, 100, 489-496. [CrossRef]

133. Barrett, M.L.; Udani, J.K. A proprietary alpha-amylase inhibitor from white bean (Phaseolus vulgaris): A review of clinical studies on weight loss and glycemic control. Nutr. J. 2011, 10, 24. [CrossRef]

134. Sales, P.M.; Souza, P.M.; Simeoni, L.A.; Magalhães, P.O.; Silveira, D. $\alpha$-Amylase inhibitors: A review of raw material and isolated compounds from plant source. J. Pharm. Pharm. Sci. 2012, 15, 141-183. [CrossRef]

135. Payab, M.; Hasani-Ranjbar, S.; Shahbal, N.; Qorbani, M.; Aletaha, A.; Haghi-Aminjan, H.; Soltani, A.; Khatami, F.; Nikfar, S.; Hassani, S.; et al. Effect of the herbal medicines in obesity and metabolic syndrome: A systematic review and meta-analysis of clinical trials. Phytother. Res. 2020, 34, 526-545. [CrossRef]

136. Celleno, L.; Tolaini, M.V.; D’Amore, A.; Perricone, N.V.; Preuss, H.G. A dietary supplement containing standardized Phaseolus vulgaris extract influences body composition of overweight men and women. Int. J. Med. Sci. 2007, 4, 45-52. [CrossRef]

137. Shutler, S.M.; Bircher, G.M.; Tredger, J.A.; Morgan, L.M.; Walker, A.F.; Low, A.G. The effect of daily baked bean (Phaseolus vulgaris) consumption on the plasma lipid levels of young, normo-cholesterolaemic men. Br. J. Nutr. 1989, 61, 257-265. [CrossRef]

138. Anderson, J.W.; Gustafson, N.J.; Spencer, D.B.; Tietyen, J.; Bryant, C.A. Serum lipid response of hypercholesterolemic men to single and divided doses of canned beans. Am. J. Clin. Nutr. 1990, 51, 1013-1019. [CrossRef]

139. Reverri, E.J.; Randolph, J.M.; Steinberg, F.M.; Kappagoda, C.T.; Edirisinghe, I.; Burton-Freeman, B.M. black beans, fiber, and antioxidant capacity pilot study: Examination of whole foods vs. functional components on postprandial metabolic, oxidative stress, and inflammation in adults with metabolic syndrome. Nutrients 2015, 7, 6139-6154. [CrossRef]

140. Spadafranca, A.; Rinelli, S.; Riva, A.; Morazzoni, P.; Magni, P.; Bertoli, S.; Battezzati, A. Phaseolus vulgaris extract affects glycometabolic and appetite control in healthy human subjects. Br. J. Nutr. 2013, 109, 1789-1795. [CrossRef]

141. Reverri, E.J.; Randolph, J.M.; Kappagoda, C.T.; Park, E.; Edirisinghe, I.; Burton-Freeman, B.M. Assessing beans as a source of intrinsic fiber on satiety in men and women with metabolic syndrome. Appetite 2017, 118, 75-81. [CrossRef]

142. Micheli, L.; Lucarini, E.; Trallori, E.; Avagliano, C.; De Caro, C.; Russo, R.; Calignano, A.; Ghelardini, C.; Pacini, A.; Di Cesare Mannelli, L. Phaseolus vulgaris L. extract: Alpha-amylase inhibition against metabolic syndrome in mice. Nutrients 2019, 11, 1778. [CrossRef]

143. Zaru, A.; Maccioni, P.; Riva, A.; Morazzoni, P.; Bombardelli, E.; Gessa, G.L.; Morazzoni, P.; Carai, M.A.M. Reducing effect of a combination of Phaseolus vulgaris and Cynara scolymus extracts on operant self-administration of a chocolate-flavoured beverage in rats. Phytother. Res. 2013, 27, 944-947. [CrossRef]

144. Li, G.-H.; Shi, Y.-H.; Liu, H.; Le, G.-W. Antihypertensive effect of alcalase generated mung bean protein hydrolysates in spontaneously hypertensive rats. Eur. Food Res. Technol. 2006, 222, 733-736. [CrossRef]

145. Zheng, Y.; Li, Y.; Zhang, Y.; Ruan, X.; Zhang, R. Purification, characterization, synthesis, in vitro ACE inhibition and in vivo antihypertensive activity of bioactive peptides derived from oil palm kernel glutelin-2 hydrolysates. J. Funct. Foods 2017, 28 , 48-58. [CrossRef]

146. Mojica, L.; de Mejia, E.G.; Granados-Silvestre, M.Á.; Menjivar, M. Evaluation of the hypoglycemic potential of a black bean hydrolyzed protein isolate and its pure peptides using in silico, in vitro and in vivo approaches. J. Funct. Foods 2017, 31, 274-286. [CrossRef]

147. Nichenametla, S.N.; Weidauer, L.A.; Wey, H.E.; Beare, T.M.; Specker, B.L.; Dey, M. Resistant starch type 4-enriched diet lowered blood cholesterols and improved body composition in a double blind controlled cross-over intervention. Mol. Nutr. Food Res. 2014, 58, 1365-1369. [CrossRef]

148. Park, O.J.; Ekang, N.; Chang, M.J.; Kim, W.K. Resistant starch supplementation influences blood lipid concentrations and glucose control in overweight subjects. J. Nutr. Sci. Vitaminol. 2004, 50, 93-99. [CrossRef]

149. den Hartigh, L.J. Conjugated linoleic acid effects on cancer, obesity, and atherosclerosis: A review of pre-clinical and human trials with current perspectives. Nutrients 2019, 11,370. [CrossRef]

150. Park, Y.; Albright, K.J.; Liu, W.; Storkson, J.M.; Cook, M.E.; Pariza, M.W. Effect of conjugated linoleic acid on body composition in mice. Lipids 1997, 32, 853-858. [CrossRef]

151. Miller, J.R.; Siripurkpong, P.; Hawes, J.; Majdalawieh, A.; Ro, H.-S.; McLeod, R.S. The trans-10, cis-12 isomer of conjugated linoleic acid decreases adiponectin assembly by PPAR $\gamma$-dependent and PPAR $\gamma$-independent mechanisms. J. Lipid Res. 2008, 49, 550-562. [CrossRef]

152. Carai, M.A.; Fantini, N.; Loi, B.; Colombo, G.; Riva, A.; Morazzoni, P. Potential efficacy of preparations derived from Phaseolus vulgaris in the control of appetite, energy intake, and carbohydrate metabolism. Diabetes Metab. Syndr. Obes. Targets Ther. 2009, 2, 145-153. [CrossRef]

153. Guo, W.; Kim, S.H.; Wu, D.; Li, L.; Ortega, E.F.; Thomas, M.; Meydani, S.N.; Meydani, M. Dietary fruit and vegetable supplementation suppresses diet-induced atherosclerosis in LDL receptor knockout mice. J. Nutr. 2021, 151, 902-910. [CrossRef]

154. Khan, R.; Spagnoli, V.; Tardif, J.-C.; L'Allier, P.L. Novel anti-inflammatory therapies for the treatment of atherosclerosis. Atherosclerosis 2015, 240, 497-509. [CrossRef]

155. Alves, N.E.G.; Vasconcelos, C.M.; Bassinello, P.Z.; de Mejia, E.G.; Martino, H.S.D. Digested protein isolate from fresh and stored Carioca beans reduced markers of atherosclerosis in oxidized LDL-induced THP-1 macrophages. J. Funct. Foods 2016, 24, 97-111. [CrossRef] 
156. Neele, A.E.; Van den Bossche, J.; Hoeksema, M.A.; De Winther, M.P.J. Epigenetic pathways in macrophages emerge as novel targets in atherosclerosis. Eur. J. Pharmacol. 2015, 763, 79-89. [CrossRef]

157. Soltani, S.; Boozari, M.; Cicero, A.F.G.; Jamialahmadi, T.; Sahebkar, A. Effects of phytochemicals on macrophage cholesterol efflux capacity: Impact on atherosclerosis. Phytother. Res. 2021, 35, 2854-2878. [CrossRef]

158. Finley, J.W.; Burrell, J.B.; Reeves, P.G. Pinto bean consumption changes SCFA profiles in fecal fermentations, bacterial populations of the lower bowel, and lipid profiles in blood of humans. J. Nutr. 2007, 137, 2391-2398. [CrossRef]

159. Taga, M.S.; Miller, E.E.; Pratt, D.E. Chia seeds as a source of natural lipid antioxidants. J. Am. Oil Chem. Soc. 1984, 61, 928-931. [CrossRef]

160. Ayerza, R. The seed's oil content and fatty acid composition of chia (Salvia hispanica L.) Var. Iztac 1, grown under six tropical ecosystems conditions. Interciencia 2011, 36, 620-624.

161. Ciftci, O.N.; Przybylski, R.; Rudzińska, M. Lipid components of flax, perilla, and chia seeds. Eur. J. Lipid Sci. Technol. 2012, 114, 794-800. [CrossRef]

162. Carrero, J.J.; Martín-Bautista, E.; Baró, L.; Fonollá, J.; Jiménez, J.; Boza, J.J.; López-Huertas, E. Efectos cardiovasculares de los ácidos grasos omega-3 y alternativas para incrementar su ingesta. Nutr. Hosp. 2005, 20, 63-69.

163. Kritchevsky, D. Conjugated linoleic acid in experimental atherosclerosis. In Advances in Conjugated Linoleic Acid Research; AOCS Publishing: New York, NY, USA, 2020; Volume 2, pp. 292-301.

164. Kritchevsky, D.; Tepper, S.A.; Wright, S.; Czarnecki, S.K.; Wilson, T.A.; Nicolosi, R.J. Conjugated linoleic acid isomer effects in atherosclerosis: Growth and regression of lesions. Lipids 2004, 39, 611-616. [CrossRef]

165. Wilson, T.A.; Nicolosi, R.J.; Chrysam, M.; Kritchevsky, D. Conjugated linoleic acid reduces early aortic atherosclerosis greater than linoleic acid in hypercholesterolemic hamsters. Nutr. Res. 2000, 20, 1795-1805. [CrossRef]

166. Glore, S.R.; Van Treeck, D.; Knehans, A.W.; Guild, M. Soluble fiber and serum lipids: A literature review. J. Am. Diet. Assoc. 1994, 94, 425-436. [CrossRef]

167. Kritchevsky, D. Protein and atherosclerosis. J. Nutr. Sci. Vitaminol. 1990, 36, S81-S86. [CrossRef]

168. Navab, M.; Anantharamaiah, G.; Hama, S.; Garber, D.W.; Chaddha, M.; Hough, G.; Lallone, R.; Fogelman, A.M. Oral administration of an Apo AI mimetic peptide synthesized from D-amino acids dramatically reduces atherosclerosis in mice independent of plasma cholesterol. Circulation 2002, 105, 290-292. [CrossRef]

169. Wang, S.; Wu, D.; Matthan, N.R.; Lamon-Fava, S.; Lecker, J.L.; Lichtenstein, A.H. Reduction in dietary omega-6 polyunsaturated fatty acids: Eicosapentaenoic acid plus docosahexaenoic acid ratio minimizes atherosclerotic lesion formation and inflammatory response in the LDL receptor null mouse. Atherosclerosis 2009, 204, 147-155. [CrossRef]

170. Chavez-Mendoza, C.; Sanchez, E. Bioactive Compounds from Mexican varieties of the common bean (Phaseolus vulgaris): Implications for Health. Molecules 2017, 22, 1360. [CrossRef]

171. Frassinetti, S.; Gabriele, M.; Caltavuturo, L.; Longo, V.; Pucci, L. Antimutagenic and antioxidant activity of a selected lectin-free common bean (Phaseolus vulgaris L.) in two cell-based models. Plant Foods Hum. Nutr. 2015, 70, 35-41. [CrossRef]

172. Giugliano, D.; Ceriello, A.; Esposito, K. The effects of diet on inflammation: Emphasis on the metabolic syndrome. J. Am. Coll. Cardiol. 2006, 48, 677-685. [CrossRef]

173. Madrera, R.R.; Negrillo, A.C.; Valles, B.S.; Fernandez, J.J.F. Characterization of extractable phenolic profile of common bean seeds (Phaseolus vulgaris L.) in a Spanish diversity panel. Food Res. Int. 2020, 138, 109713. [CrossRef]

174. Perez-Hernandez, L.M.; Nugraheni, K.; Benohoud, M.; Sun, W.; Hernández-Álvarez, A.J.; Morgan, M.R.A.; Boesch, C.; Orfila, C. Starch Digestion Enhances Bioaccessibility of Anti-Inflammatory Polyphenols from Borlotti Beans (Phaseolus vulgaris). Nutrients 2020, 12, 295. [CrossRef]

175. Hutchins, A.M.; Winham, D.M.; Thompson, S.V. Phaseolus beans: Impact on glycaemic response and chronic disease risk in human subjects. Br. J. Nutr. 2012, 108, S52-S65. [CrossRef]

176. Chavez-Santoscoy, R.A.; Gutierrez-Uribe, J.A.; Serna-Saldivar, S.O. Effect of flavonoids and saponins extracted from black bean (Phaseolus vulgaris L.) seed coats as cholesterol micelle disruptors. Plant Foods Hum. Nutr. 2013, 68, 416-423. [CrossRef]

177. Clark, J.L.; Taylor, C.G.; Zahradka, P. Black beans and red kidney beans induce positive postprandial vascular responses in healthy adults: A pilot randomized cross-over study. Nutr. Metab. Cardiovasc. Dis. 2021, 31, 216-226. [CrossRef]

178. Graziani, D.; Ribeiro, J.; Cruz, V.; Gomes, R.; Araújo, E.; Júnior, A.S.; Tomaz, H.; Castro, C.; Fontes, W.; Batista, K.; et al. Oxidonitrergic and antioxidant effects of a low molecular weight peptide fraction from hardened bean (Phaseolus vulgaris) on endothelium. Braz. J. Med Biol. Res. 2021, 54, e10423. [CrossRef]

179. Zhu, Z.; Jiang, W.; Thompson, H.J. Edible dry bean consumption (Phaseolus vulgaris L.) modulates cardiovascular risk factors and diet-induced obesity in rats and mice. Br. J. Nutr. 2012, 108, S66-S73. [CrossRef]

180. Rubio, L.A.; Aranda-Olmedo, I.; Martin-Pedrosa, M. Inclusion of limited amounts of extruded legumes plus cereal mixes in normocaloric or obesogenic diets for rats: Effects on lipid profile. Foods 2020, 9, 704. [CrossRef]

181. Howard, B.V.; Kritchevsky, D. Phytochemicals and cardiovascular disease: A statement for healthcare professionals from the American Heart Association. Circulation 1997, 95, 2591-2593. [CrossRef]

182. Anderson, J.W.; Smith, B.M.; Washnock, C.S. Cardiovascular and renal benefits of dry bean and soya bean intake. Oilseeds Focus 2020, 6, 43-45.

183. Van Horn, L. Fiber, lipids, and coronary heart disease: A statement for healthcare professionals from the Nutrition Committee, American Heart Association. Circulation 1997, 95, 2701-2704. [CrossRef] 
184. Lavie, C.J.; Milani, R.V.; Mehra, M.R.; Ventura, H.O. Omega-3 polyunsaturated fatty acids and cardiovascular diseases. J. Am. Coll. Cardiol. 2009, 54, 585-594. [CrossRef]

185. Anand, R.G.; Alkadri, M.; Lavie, C.J.; Milani, R.V. The role of fish oil in arrhythmia prevention. J. Cardiopulm. Rehabil. Prev. 2008, 28, 92-98. [CrossRef]

186. Mozaffarian, D.; Bryson, C.L.; Lemaitre, R.N.; Burke, G.L.; Siscovick, D.S. Fish intake and risk of incident heart failure. J. Am. Coll. Cardiol. 2005, 45, 2015-2021. [CrossRef]

187. Yamagishi, K.; Iso, H.; Date, C.; Fukui, M.; Wakai, K.; Kikuchi, S.; Inaba, Y.; Tanabe, N.; Tamakoshi, A. Fish, $\omega-3$ polyunsaturated fatty acids, and mortality from cardiovascular diseases in a nationwide community-based cohort of Japanese men and women: The JACC (Japan Collaborative Cohort Study for Evaluation of Cancer Risk) study. J. Am. Coll. Cardiol. 2008, 52, 988-996. [CrossRef]

188. Galan, P.; Kesse-Guyot, E.; Czernichow, S.; Briancon, S.; Blacher, J.; Hercberg, S. Effects of B vitamins and omega 3 fatty acids on cardiovascular diseases: A randomised placebo controlled trial. BMJ 2010, 341, c6273. [CrossRef]

189. Luceri, C.; Giannini, L.; Lodovici, M.; Antonucci, E.; Abbate, R.; Masini, E.; Dolara, P. p-Coumaric acid, a common dietary phenol, inhibits platelet activity in vitro and in vivo. Br. J. Nutr. 2007, 97, 458-463. [CrossRef]

190. Prince, P.S.M.; Roy, A.J. p-Coumaric acid attenuates apoptosis in isoproterenol-induced myocardial infarcted rats by inhibiting oxidative stress. Int. J. Cardiol. 2013, 168, 3259-3266. [CrossRef]

191. Ostertag, L.M.; O’Kennedy, N.; Horgan, G.W.; Kroon, P.A.; Duthie, G.G.; de Roos, B. In vitro anti-platelet effects of simple plant-derived phenolic compounds are only found at high, non-physiological concentrations. Mol. Nutr. Food Res. 2011, 55, 1624-1636. [CrossRef]

192. Zang, L.Y.; Cosma, G.; Gardner, H.; Shi, X.; Castranova, V.; Vallyathan, V. Effect of antioxidant protection by p-coumaric acid on low-density lipoprotein cholesterol oxidation. Am. J. Physiol.-Cell Physiol. 2000, 279, C954-C960. [CrossRef]

193. Abdel-Wahab, M.H.; El-Mahdy, M.A.; Abd-Ellah, M.F.; Helal, G.K.; Khalifa, F.; Hamada, F.M. Influence of p-coumaric acid on doxorubicin-induced oxidative stress in rat's heart. Pharmacol. Res. 2003, 48, 61-65. [CrossRef]

194. Fuentes, E.; Caballero, J.; Alarcon, M.; Rojas, A.; Palomo, I. Chlorogenic acid inhibits human platelet activation and thrombus formation. PLoS ONE 2014, 9, e90699. [CrossRef]

195. Cho, H.-J.; Kang, H.-J.; Kim, Y.-J.; Lee, D.-H.; Kwon, H.-W.; Kim, Y.-Y.; Park, H.-J. Inhibition of platelet aggregation by chlorogenic acid via cAMP and cGMP-dependent manner. Blood Coagul. Fibrinolysis 2012, 23, 629-635. [CrossRef]

196. Fuentes, E.; Forero-Doria, O.; Carrasco, G.; Maricán, A.; Santos, L.S.; Alarcón, M.; Palomo, I. Effect of tomato industrial processing on phenolic profile and antiplatelet activity. Molecules 2013, 18, 11526-11536. [CrossRef]

197. Hong, Q.; Ma, Z.-C.; Huang, H.; Wang, Y.-G.; Tan, H.-L.; Xiao, C.-R.; Liang, Q.-D.; Zhang, H.-T.; Gao, Y. Antithrombotic activities of ferulic acid via intracellular cyclic nucleotide signaling. Eur. J. Pharmacol. 2016, 777, 1-8. [CrossRef]

198. Kim, M.-S.; Shin, W.-C.; Kang, D.-K.; Sohn, H.-Y. Anti-thrombosis activity of sinapic acid isolated from the lees of bokbunja wine J. Microbiol. Biotechnol. 2016, 26, 61-65. [CrossRef]

199. Kim, K.; Bae, O.-N.; Lim, K.-M.; Noh, J.-Y.; Kang, S.; Chung, K.Y.; Chung, J.-H. Novel antiplatelet activity of protocatechuic acid through the inhibition of high shear stress-induced platelet aggregation. J. Pharmacol. Exp. Ther. 2012, 343, 704-711. [CrossRef]

200. Tang, X.-L.; Liu, J.-X.; Dong, W.; Li, P.; Li, L.; Lin, C.-R.; Zheng, Y.-Q.; Cong, W.-H.; Hou, J.-C. The cardioprotective effect of protocatechuic acid on myocardial ischemia/reperfusion injury. J. Pharmacol. Sci. 2014, 125, 176-183. [CrossRef]

201. Ya, F.; Li, K.; Chen, H.; Tian, Z.; Fan, D.; Shi, Y.; Song, F.; Xu, X.; Ling, W.; Adili, R.; et al. Protocatechuic acid protects platelets from apoptosis via inhibiting oxidative stress-mediated PI3K/Akt/GSK3 $\beta$ signaling. Thromb. Haemost. 2021, 121, 931-943. [CrossRef]

202. Choi, J.-H.; Kim, S. Mechanisms of attenuation of clot formation and acute thromboembolism by syringic acid in mice. J. Funct. Foods 2018, 43, 112-122. [CrossRef]

203. Gaspar, R.S.; da Silva, S.A.; Stapleton, J.; Fontelles, J.L.L.; Sousa, H.R.; Chagas, V.T.; Alsufyani, S.; Trostchansky, A.; Gibbins, J.M.; de Andrade Paes, A.M. Myricetin, the main flavonoid in Syzygium cumini leaf, is a novel inhibitor of platelet thiol isomerases PDI and ERp5. Front. Pharmacol. 2020, 10, 1678. [CrossRef]

204. Zang, B.X.; Jin, M.; Wu, W.; Chen, W.M.; Piao, Y.Z.; Li, J.R. Antagonistic effect of myricetin on platelet activing factor. Yao Xue Хue Bao 2003, 38, 831-833.

205. Robak, J.; Korbut, R.; Shridi, F.; Swies, J.; Rzadkowska-Bodalska, H. On the mechanism of antiaggregatory effect of myricetin. Pol. J. Pharmacol. Pharm. 1988, 40, 337-340.

206. Landolfi, R.; Mower, R.L.; Steiner, M. Modification of platelet function and arachidonic acid metabolism by bioflavonoids: Structure-activity relations. Biochem. Pharmacol. 1984, 33, 1525-1530. [CrossRef]

207. Nakashima, S.; Koike, T.; Nozawa, Y. Genistein, a protein tyrosine kinase inhibitor, inhibits thromboxane A2-mediated human platelet responses. Mol. Pharmacol. 1991, 39, 475-480.

208. Gottstein, N.; Ewins, B.A.; Eccleston, C.; Hubbard, G.P.; Kavanagh, I.C.; Minihane, A.-M.; Weinberg, P.D.; Rimbach, G. Effect of genistein and daidzein on platelet aggregation and monocyte and endothelial function. Br. J. Nutr. 2003, 89, 607-615. [CrossRef]

209. Ozaki, Y.; Yatomi, Y.; Jinnai, Y.; Kume, S. Effects of genistein, a tyrosine kinase inhibitor, on platelet functions: Genistein attenuates thrombin-induced $\mathrm{Ca}^{2+}$ mobilization in human platelets by affecting polyphosphoinositide turnover. Biochem. Pharmacol. 1993, 46, 395-403. [CrossRef]

210. Dhar, A.; Paul, A.K.; Shukla, S.D. Platelet-activating factor stimulation of tyrosine kinase and its relationship to phospholipase C in rabbit platelets: Studies with genistein and monoclonal antibody to phosphotyrosine. Mol. Pharmacol. 1990, 37, 519-525. 
211. Pan, W.; Ikeda, K.; Takebe, M.; Yamori, Y. Genistein, daidzein and glycitein inhibit growth and DNA synthesis of aortic smooth muscle cells from stroke-prone spontaneously hypertensive rats. J. Nutr. 2001, 131, 1154-1158. [CrossRef]

212. Wan, Y.J.; Zhuang, P.W.; Zhang, Y.J. Antithrombotic activity of Formononetin sodium and its mechanism. Chin. J. New Drugs 2016, 25, 1355-1358.

213. Chen, Z.; Liu, S.; Cai, Y.; Xie, K.; Zhang, W.; Dong, L.; Liu, Y.; Zheng, F.; Dun, Y.; Li, N. Suppressive effect of formononetin on platelet-derived growth factor-BB-stimulated proliferation and migration of vascular smooth muscle cells. Exp. Ther. Med. 2016, 12, 1901-1907. [CrossRef]

214. Zhu, H.; Zou, L.; Tian, J.; Lin, F.; He, J.; Hou, J. Protective effects of sulphonated formononetin in a rat model of cerebral ischemia and reperfusion injury. Planta Medica 2014, 80, 262-268. [CrossRef]

215. Chtourou, Y.; Kamoun, Z.; Zarrouk, W.; Kebieche, M.; Kallel, C.; Gdoura, R.; Fetoui, H. Naringenin ameliorates renal and platelet purinergic signalling alterations in high-cholesterol fed rats through the suppression of ROS and NF-kB signaling pathways Food Funct. 2016, 7, 183-193. [CrossRef]

216. Jin, Y.-R.; Han, X.-H.; Zhang, Y.-H.; Lee, J.-J.; Lim, Y.; Chung, J.-H.; Yun, Y.-P. Antiplatelet activity of hesperetin, a bioflavonoid, is mainly mediated by inhibition of PLC- $\gamma 2$ phosphorylation and cyclooxygenase-1 activity. Atherosclerosis 2007, 194, 144-152. [CrossRef]

217. McGregor, L.; Bellangeon, M.; Chignier, E.; Lerond, L.; Rousselle, C.; McGregor, J.L. Effect of a micronized purified flavonoid fraction on in vivo platelet functions in the rat. Thromb. Res. 1999, 94, 235-240. [CrossRef]

218. Pignatelli, P.; Pulcinelli, F.M.; Celestini, A.; Lenti, L.; Ghiselli, A.; Gazzaniga, P.P.; Violi, F. The flavonoids quercetin and catechin synergistically inhibit platelet function by antagonizing the intracellular production of hydrogen peroxide. Am. J. Clin. Nutr. 2000, 72, 1150-1155. [CrossRef]

219. Neiva, T.J.C.; Morais, L.; Polack, M.; Simoes, C.M.O.; D’Amico, E.A. Effects of catechins on human blood platelet aggregation and lipid peroxidation. Phytother. Res. 1999, 13, 597-600. [CrossRef]

220. Blache, D.; Durand, P.; Prost, M.; Loreau, N. (+)-Catechin inhibits platelet hyperactivity induced by an acute iron load in vivo. Free. Radic. Biol. Med. 2002, 33, 1670-1680. [CrossRef]

221. Tzeng, S.-H.; Ko, W.-C.; Ko, F.-N.; Teng, C.-M. Inhibition of platelet aggregation by some flavonoids. Thromb. Res. 1991, 64, 91-100. [CrossRef]

222. Chung, M.-I.; Gan, K.-H.; Lin, C.-N.; Ko, F.-N.; Teng, C.-M. Antiplatelet effects and vasorelaxing action of some constituents of Formosan plants. J. Nat. Prod. 1993, 56, 929-934. [CrossRef]

223. Kim, T.-J.; Kim, J.-H.; Jin, Y.-R.; Yun, Y.-P. The inhibitory effect and mechanism of luteolin 7-glucoside on rat aortic vascular smooth muscle cell proliferation. Arch. Pharmacal Res. 2006, 29, 67-72. [CrossRef]

224. Teng, C.-M.; Li, H.-L.; Wu, T.-S.; Huang, S.-C.; Huang, T.-F. Antiplatelet actions of some coumarin compounds isolated from plant sources. Thromb. Res. 1992, 66, 549-557. [CrossRef]

225. Zaragozá, C.; Monserrat, J.; Mantecón, C.; Villaescusa, L.; Zaragozá, F.; Álvarez-Mon, M. Antiplatelet activity of flavonoid and coumarin drugs. Vasc. Pharmacol. 2016, 87, 139-149. [CrossRef]

226. Macáková, K.; Řeháková, Z.; Mladěnka, P.; Karlíčková, J.; Filipský, T.; Říha, M.; Prasad, A.K.; Parmar, V.S.; Jahodář, L.; Pávek, P.; et al. In vitro platelet antiaggregatory properties of 4-methylcoumarins. Biochimie 2012, 94, 2681-2686. [CrossRef]

227. Deusch, E.; Gamsjäger, T.; Kress, H.-G.; Kozek-Langenecker, S.A. Binding of hydroxyethyl starch molecules to the platelet surface. Anesthesia Analg. 2003, 97, 680-683. [CrossRef]

228. Freedman, J.E.; Farhat, J.H.; Loscalzo, J.; Keaney, J.F. $\alpha$-tocopherol inhibits aggregation of human platelets by a protein kinase C-dependent mechanism. Circulation 1996, 94, 2434-2440. [CrossRef]

229. Liu, M.; Wallmon, A.; Olsson-Mortlock, C.; Wallin, R.; Saldeen, T. Mixed tocopherols inhibit platelet aggregation in humans: Potential mechanisms. Am. J. Clin. Nutr. 2003, 77, 700-706. [CrossRef]

230. Gajos, G.; Rostoff, P.; Undas, A.; Piwowarska, W. Effects of polyunsaturated omega-3 fatty acids on responsiveness to dual antiplatelet therapy in patients undergoing percutaneous coronary intervention: The OMEGA-PCI (OMEGA-3 fatty acids after pci to modify responsiveness to dual antiplatelet therapy) study. J. Am. Coll. Cardiol. 2010, 55, 1671-1678.

231. Gajos, G.; Zalewski, J.; Rostoff, P.; Nessler, J.; Piwowarska, W.; Undas, A. Reduced thrombin formation and altered fibrin clot properties induced by polyunsaturated omega-3 fatty acids on top of dual antiplatelet therapy in patients undergoing percutaneous coronary intervention (OMEGA-PCI clot). Arterioscler. Thromb. Vasc. Biol. 2011, 31, 1696-1702. [CrossRef]

232. Cohen, M.G.; Rossi, J.S.; Garbarino, J.; Bowling, R.; Motsinger-Reif, A.A.; Schuler, C.; Dupont, A.G.; Gabriel, D. Insights into the inhibition of platelet activation by omega-3 polyunsaturated fatty acids: Beyond aspirin and clopidogrel. Thromb. Res. 2011, 128, 335-340. [CrossRef]

233. Song, F.; Zhu, Y.; Shi, Z.; Tian, J.; Deng, X.; Ren, J.; Andrews, M.C.; Ni, H.; Ling, W.; Yang, Y. Plant food anthocyanins inhibit platelet granule secretion in hypercholesterolaemia: Involving the signalling pathway of PI3K-Akt. Thromb. Haemost. 2014, 111, 981-991. [CrossRef]

234. Yang, Y.; Shi, Z.; Reheman, A.; Jin, J.W.; Li, C.; Wang, Y.; Andrews, M.C.; Chen, P.; Zhu, G.; Ling, W.; et al. Plant food delphinidin3-glucoside significantly inhibits platelet activation and thrombosis: Novel protective roles against cardiovascular diseases. PLoS ONE 2012, 7, e37323. [CrossRef]

235. Yao, Y.; Chen, Y.; Adili, R.; McKeown, T.; Chen, P.; Zhu, G.; Li, D.; Ling, W.; Ni, H.; Yang, Y. Plant-based food cyanidin-3-glucoside modulates human platelet glycoprotein VI signaling and inhibits platelet activation and thrombus formation. J. Nutr. 2017, 147, 1917-1925. [CrossRef] 
236. Ku, S.-K.; Yoon, E.-K.; Lee, W.; Kwon, S.; Lee, T.; Bae, J.-S. Antithrombotic and antiplatelet activities of pelargonidin in vivo and in vitro. Arch. Pharmacal Res. 2016, 39, 398-408. [CrossRef]

237. Ji, H.; Delker, S.L.; Li, H.; Martásek, P.; Roman, L.J.; Poulos, T.L.; Silverman, R.B. Exploration of the active site of neuronal nitric oxide synthase by the design and synthesis of pyrrolidinomethyl 2-aminopyridine derivatives. J. Med. Chem. 2010, 53, 7804-7824. [CrossRef]

238. Hopper, P.C.W. Virtual Screening and Molecular Docking Studies of Compounds from Phaseolus vulgaris against Nitric Oxide Synthase. In Proceedings of the International Conference on Bioscience, Biochemistry and Bioinformatics (CBBB 2011), Singapore, 26-28 February 2011.

239. Ngoh, Y.-Y.; Lim, T.S.; Gan, C.-Y. Screening and identification of five peptides from pinto bean with inhibitory activities against $\alpha$-amylase using phage display technique. Enzym. Microb. Technol. 2016, 89, 76-84. [CrossRef]

240. Hermoso, J.; Pignol, D.; Kerfelec, B.; Crenon, I.; Chapus, C.; Fontecilla-Camps, J.C. Lipase activation by nonionic detergents: The crystal structure of the porcine lipase-colipase-tetraethylene glycol monooctyl ether complex. J. Biol. Chem. 1996, 271, 18007-18016. [CrossRef]

241. Cooper, J.B.; Khan, G.; Taylor, G.; Tickle, I.J.; Blundell, T.L. X-ray analyses of aspartic proteinases: II. Three-dimensional structure of the hexagonal crystal form of porcine pepsin at 2.3 A resolution. J. Mol. Biol. 1990, 214, 199-222. [CrossRef]

242. Lebon, G.; Warne, T.; Edwards, P.C.; Bennett, K.; Langmead, C.J.; Leslie, A.G.W.; Tate, C.G. Agonist-bound adenosine A 2A receptor structures reveal common features of GPCR activation. Nature 2011, 474, 521-525. [CrossRef]

243. Zhang, D.; Gao, Z.-G.; Zhang, K.; Kiselev, E.; Crane, S.; Wang, J.; Paoletta, S.; Yi, C.; Ma, L.; Zhang, W.; et al. Two disparate ligand-binding sites in the human P2Y1 receptor. Nature 2015, 520, 317-321. [CrossRef]

244. Fan, H.; Chen, S.; Yuan, X.; Han, S.; Zhang, H.; Xia, W.; Xu, Y.; Zhao, Q.; Wu, B. Structural basis for ligand recognition of the human thromboxane A(2) receptor. Nat. Chem. Biol. 2019, 15, 27-33. [CrossRef]

245. Grodsky, N.; Li, Y.; Bouzida, D.; Love, R.; Jensen, J.; Nodes, B.; Nonomiya, J.; Grant, S. Structure of the catalytic domain of human protein kinase C beta II complexed with a bisindolylmaleimide inhibitor. Biochemistry 2006, 45, 13970-13981. [CrossRef]

246. Sutton, R.B.; Sprang, S.R. Structure of the protein kinase Cbeta phospholipid-binding C2 domain complexed with Ca ${ }^{2+}$. Structure 1998, 6, 1395-1405. [CrossRef]

247. Newport, T.D.; Sansom, M.S.P.; Stansfeld, P.J. The MemProtMD database: A resource for membrane-embedded protein structures and their lipid interactions. Nucleic Acids Res. 2018, 47, D390-D397. [CrossRef]

248. Fuentes, E.; Badimon, L.; Caballero, J.; Padró, T.; Vilahur, G.; Alarcón, M.; Pérez, P.; Palomo, I. Protective mechanisms of adenosine 5'-monophosphate in platelet activation and thrombus formation. Thromb. Haemost. 2014, 111, 491-507. [CrossRef]

249. Zhang, J.; Zhang, K.; Gao, Z.-G.; Paoletta, S.; Zhang, D.; Han, G.W.; Li, T.; Ma, L.; Zhang, W.; Müller, C.E.; et al. Agonist-bound structure of the human P2Y 12 receptor. Nature 2014, 509, 119-122. [CrossRef]

250. Bugert, P.; Fischer, L.; Althaus, K.; Knöfler, R.; Bakchoul, T. Platelet dysfunction caused by a novel thromboxane A2 receptor mutation and congenital thrombocytopenia in a case of mild bleeding. Platelets 2020, 31, 276-279. [CrossRef]

251. Bauer, J.; Ripperger, A.; Frantz, S.; Ergün, S.; Schwedhelm, E.; Benndorf, R.A. Pathophysiology of isoprostanes in the cardiovascular system: Implications of isoprostane-mediated thromboxane A 2 receptor activation. Br. J. Pharmacol. 2014, 171, 3115-3131. [CrossRef]

252. Harper, M.T.; Poole, A.W. Diverse functions of protein kinase C isoforms in platelet activation and thrombus formation. J. Thromb. Haemost. 2010, 8, 454-462. [CrossRef] 